\title{
Synaptic Targets of Medial Septal Projections in the Hippocampus and Extrahippocampal Cortices of the Mouse
}

\author{
[DGunes Unal, ${ }^{1}$ Abhilasha Joshi, ${ }^{1}$ (Tim J. Viney, ${ }^{1}$ Viktor Kis, ${ }^{1,2}$ and Peter Somogyi ${ }^{1}$ \\ ${ }^{1}$ Medical Research Council Brain Network Dynamics Unit, Department of Pharmacology, University of Oxford, Oxford OX1 3TH, United Kingdom, and \\ ${ }^{2}$ Department of Anatomy, Cell and Developmental Biology, Eötvös Loránd University, 1117 Budapest, Hungary
}

\begin{abstract}
Temporal coordination of neuronal assemblies among cortical areas is essential for behavioral performance. GABAergic projections from the medial septum and diagonal band complex exclusively innervate GABAergic interneurons in the rat hippocampus, contributing to the coordination of neuronal activity, including the generation of theta oscillations. Much less is known about the synaptic target neurons outside the hippocampus. To reveal the contribution of synaptic circuits involving the medial septum of mice, we have identified postsynaptic cortical neurons in wild-type and parvalbumin-Cre knock-in mice. Anterograde axonal tracing from the septum revealed extensive innervation of the hippocampus as well as the subiculum, presubiculum, parasubiculum, the medial and lateral entorhinal cortices, and the retrosplenial cortex. In all examined cortical regions, many septal GABAergic boutons were in close apposition to somata or dendrites immunopositive for interneuron cell-type molecular markers, such as parvalbumin, calbindin, calretinin, N-terminal EFhand calcium-binding protein 1, cholecystokinin, reelin, or a combination of these molecules. Electron microscopic observations revealed septal boutons forming axosomatic or axodendritic type II synapses. In the CA1 region of hippocampus, septal GABAergic projections exclusively targeted interneurons. In the retrosplenial cortex, $93 \%$ of identified postsynaptic targets belonged to interneurons and the rest to pyramidal cells. These results suggest that the GABAergic innervation from the medial septum and diagonal band complex contributes to temporal coordination of neuronal activity via several types of cortical GABAergic interneurons in both hippocampal and extrahippocampal cortices. Oscillatory septal neuronal firing at delta, theta, and gamma frequencies may phase interneuron activity.
\end{abstract}

Key words: entorhinal; hippocampus; inhibition; interneuron; medial septum; retrosplenial

Significance Statement

Diverse types of GABAergic interneurons coordinate the firing of cortical principal cells required for memory processes. During wakefulness and rapid eye movement sleep, the rhythmic firing of cortical GABAergic neurons plays a key role in governing network activity. We investigated subcortical GABAergic projections in the mouse that extend from the medial septum/diagonal band nuclei to GABAergic neurons in the hippocampus and related extrahippocampal cortical areas, including the medial entorhinal cortex. These areas contribute to navigation and show theta rhythmic activity. We found selective GABAergic targeting of different groups of cortical GABAergic neurons, immunoreactive for combinations of cell-type markers. As septal GABAergic neurons also fire rhythmically, their selective innervation of cortical GABAergic neurons suggests an oscillatory synchronization of neuronal activity across functionally related areas.

\section{Introduction}

Theta frequency oscillations $(4-12 \mathrm{~Hz})$ in the rodent hippocampus and related cortical areas are highly correlated with vigilant

Received July 10, 2015; revised Sept. 5, 2015; accepted 0ct. 9, 2015.

Author contributions: G.U., A.J., T.J.V., V.K., and P.S. designed research; G.U., A.J., T.J.V., V.K., and P.S. performed research; G.U., A.J., T.J.V., V.K., and P.S. contributed unpublished reagents/analytic tools; G.U., A.J., T.J.V., V.K., and P.S. analyzed data; G.U., A.J., T.J.V., V.K., and P.S. wrote the paper.

This work was supported by the Medical Research Council (MC_UU_12024/4) and the Research Councils UK (Open Access). G.U. is supported by the European Blaschko Visiting Research Fellowship of the Department of Pharmacology and Linacre College. A.J. is supported by a Felix Doctoral Scholarship. We thank Kristina Wagner and Ben Micklem for their excellent technical assistance and electron microscopic data. We are grateful to Masahiko behavioral states, including navigation and rapid eye movement sleep. Lesion or inactivation of the medial septum (MS) disrupts theta oscillations in the hippocampus and medial entorhinal cortex (mEC; Rawlins et al., 1979; Mizumori et al., 1990; Jeffery et al., 1995; McNaughton et al., 2006), alters the spatial periodicity of mEC grid cells (Brandon et al., 2011; Koenig et al., 2011), and

Watanabe (Department of Anatomy, Hokkaido University Graduate School of Medicine) for the gift antibodies. We also thank Ray Guillery, Tamás Freund, Balazs Hangya, Linda Katona, and Viktor Varga for comments on an earlier version of the manuscript.

The authors declare no competing financial interests.

This article is freely available online through the J Neurosci Author Open Choice option. 
impairs learning and spatial memory (Winson, 1978; Chrobak et al., 1989; Givens and Olton, 1994; McNaughton et al., 2006). The MS and diagonal band complex (DBC) send cholinergic (Lewis and Shute, 1967), glutamatergic (Sotty et al., 2003; Colom et al., 2005), and GABAergic (Köhler et al., 1984) projections to the hippocampus and neocortex (Henny and Jones, 2008). Selective inactivation of the noncholinergic (Dwyer et al., 2007) or GABAergic (Pang et al., 2011) septal projections is sufficient to impair spatial memory.

In the rat hippocampus (Freund and Antal, 1988) and retrosplenial cortex (Freund and Gulyás, 1991), septal and DBC GABAergic neurons exclusively target GABAergic interneurons. These neurons are often phase coupled to the hippocampal theta rhythm (Petsche et al., 1962; King et al., 1998; Duque et al., 2000; Borhegyi et al., 2004; Hangya et al., 2009; Hassani et al., 2009). They differentially innervate diverse populations of hippocampal interneurons (Gulyás et al., 1990) that discharge on different phases of the hippocampal theta rhythm and release GABA onto distinct postsynaptic domains of the pyramidal cells (Somogyi et al., 2014). Target cell selectivity of septal GABAergic projections in the hippocampus might also apply to the interneurons of the extrahippocampal cortical areas upstream and downstream of the hippocampus (Knierim, 2015). Contrary to the finding in rats, a recent retrograde tracing study reported that injections of a monosynaptically restricted genetically modified rabies virus into the dorsal CA1 of CaMKIIa-Cre:TVA mice showed that GABAergic septal neurons provide a significant innervation to pyramidal cells (Sun et al., 2014). In contrast, the septal GABA ergic projection was suggested to innervate selectively interneurons in the mouse mEC (Gonzalez-Sulser et al., 2014).

Target selectivity of septal GABAergic projections in the mEC may explain how the stellate cells in layer II (LII) have strong spike phase-locking to theta frequency inputs (Fernandez et al., 2013) while interacting disynaptically only via inhibitory interneurons (Couey et al., 2013). Some of the $\mathrm{mEC}$ interneurons targeted by septal GABAergic axons may provide recurrent inhibition between stellate cells. As such, separate individual septal GABAergic neurons may independently contribute to hippocampal and entorhinal theta oscillations, and this can explain how theta phase precession in principal cells of the mEC may occur independently of the hippocampus (Hafting et al., 2008). Many rhythmic cortically projecting septal cells are immunopositive for parvalbumin (PV; Borhegyi et al., 2004), a marker for fast-spiking GABAergic septal neurons (Morris et al., 1999) that coexpress hyperpolarization-activated cyclic nucleotide-gated channels in the mouse (Morris et al., 2004). This subpopulation of medial septal GABAergic neurons is also phase coupled to hippocampal theta in the rat (Simon et al., 2006; Varga et al., 2008). We hypothesized that the septal GABAergic neurons, including the PV-immunopositive rhythmic subpopulation, exclusively target interneurons in extrahippocampal cortical areas, thus contributing to theta oscillations and network computations via mechanisms similar to those used in the hippocampus.

To clarify the nature of septocortical circuits, we first revealed the distribution of PV-immunopositive and PV-

Correspondence should be addressed to either Gunes Unal or Peter Somogyi, Medical Research Council Brain Network Dynamics Unit, University of Oxford, Mansfield Road, Oxford OX1 3TH, UK, E-mail: gunes.unal@pharm.ox.ac.uk or peter.somogyi@pharm.ox.ac.uk.

DOI:10.1523/JNEUROSCI.2639-15.2015

Copyright $\odot 2015$ Unal et al.

This is an Open Access article distributed under the terms of the Creative Commons Attribution License Creative Commons Attribution 4.0 International, which permits unrestricted use, distribution and reproduction in any medium provided that the original work is properly attributed. immunonegative GABAergic subpopulations in the MS and DBC that project to the hippocampus and mEC. To identify the synaptic targets of septal GABAergic neurons, we performed anterograde tracing. We have used visualization of pathways by the Clarity method (Chung et al., 2013) to obtain a large-scale view of the projection patterns. By combining anterograde tracing with immunohistochemistry, we tested for the target cell types of individual cortically projecting septal GABAergic neurons. Then, using electron microscopy, we revealed synaptic targets in the $\mathrm{CA} 1$ and retrosplenial cortex.

\section{Materials and Methods}

All experimental procedures involving animals were performed under approved project and personal licenses in accordance with the UK Animals (Scientific Procedures) Act, 1986. Adult (20-28 g) male C57BL/6J mice (Charles River) and heterozygous PV-Cre mice (B6;129P2-

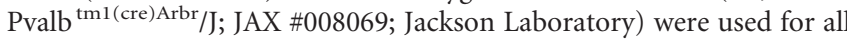
experiments. Animals were housed with littermates on a normal light/ dark cycle (lights on at 8:00 A.M; lights off at 8 P.M.) at $19-21^{\circ} \mathrm{C}$ with $\approx 55 \%$ humidity and had ad libitum access to food and water.

All surgical procedures were performed under inhalation anesthesia using isoflurane. Briefly, we made small subcutaneous injections of bupivacaine $(0.125 \%$ solution) around the incision sites on the shaved scalp. Under aseptic conditions, an incision was made in the scalp, the skull was exposed, small craniotomies were made with a drill over the target brain regions, and the dura mater was cut with a needle. Following surgery, buprenorphine (Vetergesic, $0.08 \mathrm{mg} / \mathrm{kg}$ ) was administered subcutaneously as analgesic.

Stereotaxic coordinates for the MS, $\mathrm{mEC}$, and dorsal CA1 were based on a mouse brain atlas (Paxinos and Franklin, 2003). All coordinates are in millimeters. Anteroposterior (AP) coordinates are relative to bregma; mediolateral $(\mathrm{ML})$ coordinates are relative to the sagittal suture; dorsoventral (DV) coordinates are measured from the brain surface.

Retrograde tracing. Fluorescent latex microspheres (Retrobeads, Lumafluor) were injected unilaterally into the CA1 region of dorsal hippocampus (AP, $-2.5 ; \mathrm{ML},+1.7 ; \mathrm{DV}-1.25 ; n=7$ ) and the dorsocaudal $\operatorname{mEC}(\mathrm{AP},-5.02 ; \mathrm{ML},+3$; DV $-1.95 ; n=5$ ) of C57BL/6J mice (Apps and Ruigrok, 2007). Four of these animals received combined unilateral hippocampal and entorhinal injections of Retrobeads of different colors in the same hemisphere (green into the CA1 and red into mEC; 200 $\mathrm{nl} /$ site). Injections were made with glass pipettes (tip diameter: 10-15 $\mu \mathrm{m}$ ) attached to the tip of $1 \mu \mathrm{l}$ syringes (SGE) at a rate of $40 \mathrm{nl} / \mathrm{min}$ using a pressure pump. The pipette was left in place for $10 \mathrm{~min}$ after each injection to minimize dorsal diffusion. Mice were fixed by perfusion (see below) 7-16 d after the injections. Retrogradely labeled somata in the septal and diagonal band nuclei were tested for their immunoreactivity to choline acetyltransferase (ChAT), PV, calbindin (CB), and calretinin (CR; see Immunohistochemistry). Brain sections and the positions of cells were recorded with Neurolucida software (MBF Bioscience) under epifluorescence illumination.

Anterograde tracing. We injected the anterograde tracer Phaseolus vulgaris-leucoagglutinin (PHAL; Vector Laboratories; Gerfen and Sawchenko, 1984) into the MS (AP, +0.85; ML, 0 ; DV -3.6) of four mice. The tracer was dissolved as a $2.5 \%$ solution in $0.1 \mathrm{~m}$ phosphate buffer (PB) and iontophoretically injected through a glass pipette (tip diameter: $12-18 \mu \mathrm{m}$ ) using positive $5 \mu \mathrm{A}$ current pulses, on and off every $7 \mathrm{~s}$ for 15 $\mathrm{min}$. To minimize tissue damage and dorsal diffusion, the electrode was placed in the MS 15 min before the stimulation and retracted 5 min after the end of stimulation. Following recovery, mice were kept for 1 week until perfusion fixation.

We have performed anterograde Cre-dependent adeno-associated virus (AAV) injections into the MS (AP, +0.85; ML, 0 ; DV, -3.6) of seven PV-Cre mice. We pressure-injected $400 \mathrm{nl}$ of $\mathrm{pAAV}_{2}$-EF1a-DIO-EYFP (Vector Biolabs) in $10 \mathrm{~min}$ using $1 \mu \mathrm{l}$ syringes attached to a pressure pump. Mice were fixed by perfusion 3 weeks after injections.

Tissue processing. All the Retrobead-injected and PHAL-injected mice and five AAV-injected PV-Cre mice were deeply anesthetized with sodium pentobarbital $(50 \mathrm{mg} / \mathrm{kg}$, i.p.) and transcardially perfused at the 
end of their survival times with $0.1 \mathrm{M}$ PB followed by a fixative containing $0.1 \mathrm{M} \mathrm{PB}, 4 \%$ depolymerized paraformaldehyde, and $15 \% \mathrm{v} / \mathrm{v}$ saturated picric acid, $\mathrm{pH}$ 7.4. The perfusion solution was supplemented with $0.05 \%$ glutaraldehyde for PHAL-injected mice and with $0.3 \%$ glutaraldehyde for two AAV-injected PV-Cre mice (animals GU41 and GU42). Following overnight postfixation in a glutaraldehyde-free fixative, brains were washed thoroughly in $0.1 \mathrm{M} \mathrm{PB}$ and sectioned coronally or horizontally at $60-80 \mu \mathrm{m}$ thickness using a Leica VT 1000S vibratome (Leica Microsystems). Sections were stored in $0.1 \mathrm{M} \mathrm{PB}$ with $0.05 \%$ sodium azide at $4^{\circ} \mathrm{C}$.

Two AAV-injected mice (animals GU31 and GU32) were processed with the Clarity method (Chung et al., 2013) for uninterrupted observation of trajectories of labeled axons in thick sections using epifluorescence microscopy. The original Clarity protocol was applied with acrylamide-containing hydrogel solution to both brains, which were first processed by electrophoretic tissue clearing (ETC) for $48 \mathrm{~h}$ and then cut into 500- $\mu \mathrm{m}$-thick sections for passive clearing of the lipids. Briefly, mice were perfused transcardially with PBS $(20 \mathrm{ml})$ followed by the hydrogel solution $(20 \mathrm{ml})$. After 2 nights of postfixation in a $50 \mathrm{ml}$ tube filled with $20 \mathrm{ml}$ of the same solution at $4^{\circ} \mathrm{C}$, the air in the tube was replaced with nitrogen for polymerization at $37^{\circ} \mathrm{C}(3-6 \mathrm{~h})$. The polymerized hydrogel around the brain was manually removed before washing the tissue with the clearing solution (4\% SDS and $200 \mathrm{~mm}$ boric acid in distilled $\mathrm{H}_{2} \mathrm{O}, \mathrm{pH}$ 8.5) overnight at room temperature (RT). The brains were washed again with the clearing solution for $48 \mathrm{~h}$ at $37^{\circ} \mathrm{C}$ and transferred to the ETC chamber for active removal of the lipids in the same solution for $48 \mathrm{~h}\left(30 \pm 4 \mathrm{~V} ; 37^{\circ} \mathrm{C}\right)$. The brains were then washed with PBS containing $0.3 \%$ Triton X-100 (PBS-Tx) overnight and cut into $500-\mu \mathrm{m}$-thick sections, which were transferred to a $37^{\circ} \mathrm{C}$ incubator for 7-10 d. Finally, the Clarity-processed thick sections were washed with PBS-Tx overnight and either mounted in 500- $\mu$ m-thick imaging spacers with FocusClear (CelExplorer Labs) or stored in PBS-Tx at $4^{\circ} \mathrm{C}$ for subsequent immunohistochemistry.

Immunohistochemistry. Tissue penetration of $60-80-\mu \mathrm{m}$-thick sections by antibodies was achieved by either using TBS containing $0.3 \%$ Triton X-100 (TBS-Tx) in all base solutions and washes or by treating sections with two rounds of "freeze-thaw" (FT), for which TBS-Tx was replaced with TBS in all subsequent solutions. For FT, sections were cryoprotected in $20 \%$ sucrose solution in $0.1 \mathrm{M} \mathrm{PB}$ for $\geq 3 \mathrm{~h}$ before rapidly freezing sections over liquid nitrogen then rapidly thawing in buffer. After FT, sections were washed $\geq 3$ times for $10 \mathrm{~min}$ in $0.1 \mathrm{M}$ PB. Clarityprocessed sections were always incubated in PBS-Tx and did not require tissue permeabilization or blocking. The $60-80-\mu \mathrm{m}$-thick sections were first blocked for $1 \mathrm{~h}$ at RT in $20 \%$ normal horse serum (NHS) or normal goat serum (NGS), depending on the species used to raise the secondary antibody. After blocking, most sections were incubated in primary antibody solution containing $1 \% \mathrm{NHS} / \mathrm{NGS}$ for $2-4 \mathrm{~d}$ at $4^{\circ} \mathrm{C}$; Clarityprocessed sections were incubated for $5 \mathrm{~d}$ at RT. Negative controls for the specificity of the method were processed in parallel and lacked the primary antibodies. Primary antibodies (Table 1) were detected with fluorophore-conjugated secondary antibodies for wide-field epifluorescence and confocal microscopy, and with the immunoperoxidase method for electron microscopy (see below). Molecule, species, dilution, and method for the primary antibodies are as follows: calbindin, rabbit, 1:5000 for immunofluorescence, 1:500 for Clarity; calretinin, rabbit, 1:1000 for immunofluorescence, 1:100 for Clarity; N-terminal EF-hand calcium-binding protein 1 (NECAB1), mouse, 1:500 for immunofluorescence; neuronal nitric oxide synthase (nNOS), mouse, 1:500 for immunofluorescence; PV, goat, 1:1000 for immunofluorescence, 1:100 for Clarity; PV, guinea pig, 1:5000 for immunofluorescence, 1:500 for Clarity; PV, rabbit, 1:1000 for immunofluorescence; special AT-rich sequence-binding protein-1 (SATB1), goat, 1:200 for immunofluorescence; SATB1, rabbit, 1:1000 for immunofluorescence; vesicular GABA transporter (VGAT), guinea pig, 1:500 for immunofluorescence; VGAT, rabbit, 1:500 for immunofluorescence (Viney et al., 2013, their supplementary Table 2). For immunofluorescence labeling, $60-80$ - $\mu$ m-thick sections were simultaneously processed with $\leq 4$ primary antibodies. After primary antibody incubation, sections were washed three times for 10 min and transferred to a secondary antibody solution containing $1 \%$ NHS/NGS for $4 \mathrm{~h}$ at RT or overnight at $4^{\circ} \mathrm{C}$. Antibody fluorophores were chosen to minimize spectral overlap (see below). Clarity-processed sections were washed overnight in PBS-Tx and transferred to the secondary antibody solution for $2 \mathrm{~d}$ at RT.

The following secondary antibodies were used: donkey anti-rabbit Alexa Fluor 405 (1:250 dilution; catalog \#A31556; Invitrogen); donkey anti-mouse, anti-goat, or anti-guinea pig DyLight405 (1:250; 715-475151, 705-475-147, 706-475-148, respectively; Jackson ImmunoResearch Laboratories); donkey anti-chicken or anti-guinea pig Alexa Fluor 488 (1:1000, 1:400; 703-545-155, 706-485-148, respectively; Jackson ImmunoResearch Laboratories); donkey anti-rabbit or anti-goat Alexa Fluor 488 (1:400; A21206, A11055, respectively; Invitrogen); donkey antirabbit, anti-goat, anti-sheep, anti-mouse, or anti-guinea pig Cy3 (1:400; 711-165-152, 705-165-147, 713-165-147, 715-165-151, 706-165-148, respectively; Jackson ImmunoResearch Laboratories); donkey anti-rabbit, anti-goat, anti-sheep, anti-mouse, or anti-guinea pig Cy5 (1:250; 711175-152, 705-175-147, 713-175-147, 715-175-151, 706-175-148, respectively; Jackson ImmunoResearch Laboratories); donkey anti-rabbit, anti-goat, or anti-mouse DyLight 649 (1:250; 711-495-152, 705-495-147, 715-495-151, respectively; Jackson ImmunoResearch Laboratories), donkey anti-sheep or anti-guinea pig Alexa Fluor 647 (1:250; 713-605147, 706-605-148, respectively; Jackson ImmunoResearch Laboratories). For electron microscopy, we used the following secondary antibodies from Vector Labs: biotinylated donkey anti-goat IgG (1:100 in TBS containing $1 \%$ NHS), biotinylated goat anti-chicken IgG (1:100 in TBS containing $1 \% \mathrm{NGS}$ ), and biotinylated goat anti-rabbit IgG (1:100 in TBS containing $1 \%$ NGS).

Following secondary antibody incubation, $60-80-\mu$ m-thick immunofluorescence sections were washed three times for $10 \mathrm{~min}$ each and mounted on glass slides in methyl salicylate (Retrobead sections only) or VectaShield. Clarity-processed sections were washed for $2 \mathrm{~d}$ at RT before mounting.

Confocal microscopy. Sections were first observed with a wide-field epifluorescence microscope (Leitz DMRB; Leica Microsystems) equipped with PL Fluotar objectives. Multichannel fluorescence images were acquired with ZEN 2008 software v5.0 on a Zeiss LSM 710 laser scanning confocal microscope (Zeiss Microscopy), equipped with DIC M27 Plan-Apochromat 40×/1.3 numerical aperture, DIC M27 PlanApochromat $63 \times / 1.4$ numerical aperture, and $\alpha$ Plan-Apochromat $100 \times / 1.46$ numerical aperture oil-immersion objectives. The following channel specifications were used (laser/excitation wavelength, beam splitter, emission spectral filter) for detection of Alexa405, Alexa488/ EYFP, Cy3, and Cy5: 405-30 solid-state $405 \mathrm{~nm}$ with attenuation filter ND04, MBS-405, 409-499 nm; argon $488 \mathrm{~nm}$, MBS-488, 493-542 nm; HeNe 543 nm, MBS-458/543, 552-639 nm; HeNe 633 nm, MBS-488/ $543 / 633,637-757 \mathrm{~nm}$. The pinhole size was set to 1 Airy unit for the shortest wavelength while, to keep all channels at the same optical slice thickness, the pinhole sizes of the longer wavelength channels were adjusted to values $<1$ Airy unit. Thus, optical section thickness for all channels was based on the set pinhole size for the shortest wavelength channel.

Electron microscopy. Observations of the CA1 were made in mice that received injections of PHAL (animals AJ10 and TV39) or AAV (animals AJ13 and GU42). Synaptic junctions between labeled boutons and their postsynaptic targets were identified in strata lacunosum-moleculare, radiatum, pyramidale, and oriens. Target neurons of cortically projecting GABAergic MS cells were documented in the granular retrosplenial cortex of two PHAL-injected animals (AJ04 and TV39), and boutons were identified in cortical layers II-VI.

Following FT and blocking (as above), sections were incubated in primary antibody solution for 2 nights at $4^{\circ} \mathrm{C}$, followed by overnight incubation in secondary antibody solution and $2 \mathrm{~d}$ with a 1:100 dilution of avidin/biotin complex (Vector Labs) in TBS at $4^{\circ} \mathrm{C}$. Sections were reacted with a solution of $0.05 \%$ diaminobenzidine and $0.002 \%$ hydrogen peroxide in Tris buffer for $\approx 10 \mathrm{~min}$ in the dark. After washing in $0.1 \mathrm{M}$ PB several times to stop the reaction, sections were treated with $1 \%$ osmium tetroxide solution in $0.1 \mathrm{M} \mathrm{PB}$ for $1 \mathrm{~h}$. After washing several times in $\mathrm{PB}$, sections were dehydrated in a graded series of alcohol (70, 90,95 , and $100 \%$ ) followed by propylene oxide. Uranyl acetate (1\%) was added to the $70 \%$ alcohol for $35 \mathrm{~min}$ for contrast enhancement. Dehy- 
Table 1. Primary antibodies ${ }^{a}$

\begin{tabular}{|c|c|c|c|c|c|}
\hline Molecule & Host and antibody & $\begin{array}{l}\text { Dilution and } \\
\text { procedure }\end{array}$ & Source & Antigen & Specificity information \\
\hline$C B$ & Goat, polyclonal & $1: 1000$, IF & $\begin{array}{l}\text { Frontier Institute; code: } \\
\text { Calbindin-Go-Af104 }\end{array}$ & $\begin{array}{l}\text { Recombinant mouse } \\
\text { calbindin }\end{array}$ & $\begin{array}{l}\text { Immunoblot detects a single protein } \\
\text { band at } 28 \mathrm{kDa} \text { (manufacturer's } \\
\text { technical information) }\end{array}$ \\
\hline \multirow[t]{2}{*}{ CCK } & Guinea pig & $1: 1000$, IF & $\begin{array}{l}\text { Dr. M. Watanabe, Hokkaido } \\
\text { University, Japan }\end{array}$ & $\begin{array}{l}\text { Cysteine-tagged CCK-8 } \\
\text { (CDYMGWMDF) } \\
\text { coupled to } \\
\text { keyhole limpet } \\
\text { hemocyanin }\end{array}$ & $\begin{array}{l}\text { Labeling pattern as published with } \\
\text { other antibodies }\end{array}$ \\
\hline & Rabbit & $1: 500$, IF & $\begin{array}{l}\text { Dr. M. Watanabe, Hokkaido } \\
\text { University, Japan }\end{array}$ & $\begin{array}{l}\text { Cysteine-tagged C-ter- } \\
\text { minal } 9 \text { aa of pro- } \\
\text { CCK (CSAEDYEYPS) } \\
\text { coupled to keyhole } \\
\text { limpet hemocyanin }\end{array}$ & $\begin{array}{l}\text { Labeling pattern as published with } \\
\text { other antibodies }\end{array}$ \\
\hline ChAT & Goat & $\begin{array}{l}\text { 1:500, IF; } \\
1: 50, \mathrm{CL}\end{array}$ & $\begin{array}{l}\text { Chemicon (Merck Millipore); } \\
\text { code: AB144P }\end{array}$ & Human placental ChAT & $\begin{array}{l}\text { Western blot (manufacturer's tech- } \\
\text { nical information) }\end{array}$ \\
\hline$C R$ & Goat & 1:1000, IF & Swant; code: CG1 & $\begin{array}{l}\text { Recombinant human } \\
\text { calretinin }\end{array}$ & $\begin{array}{l}\text { Antibody does not label the brain of CR } \\
\text { knock-out mice (manufacturer's } \\
\text { technical information) }\end{array}$ \\
\hline GFP & Chicken, polyclonal & $\begin{array}{l}\text { 1:500, IF, EM; } \\
\text { 1:200, CL }\end{array}$ & Aves Labs; code: GFP-1020 & Recombinant GFP & $\begin{array}{l}\text { Antibody does not label the brain of } \\
\text { wild-type control mice }\end{array}$ \\
\hline $\begin{array}{l}\text { Insulin-like growth factor } \\
\text { binding protein } 5\end{array}$ & Goat, polyclonal & $1: 100$, IF & R\&D Systems; code: AF578 & $\begin{array}{l}\text { Recombinant mouse } \\
\text { myeloma cell line } \\
\text { NSO-derived insu- } \\
\text { lin-like growth } \\
\text { factor binding } \\
\text { protein } 5\end{array}$ & $\begin{array}{l}\text { Western blot (manufacturer's tech- } \\
\text { nical information) }\end{array}$ \\
\hline \multirow[t]{2}{*}{ PHAL } & Goat, polyclonal & $\begin{array}{l}1 \mu \mathrm{g} / \mathrm{ml}, \mathrm{IF} \\
\mathrm{EM}\end{array}$ & Vector: code: AS-2224 & Purified lectin & $\begin{array}{l}\text { Both react with Phaseolus } \\
\quad \text { vulgaris erythroagglutinin and }\end{array}$ \\
\hline & Rabbit, polyclonal & $\begin{array}{l}1 \mu \mathrm{g} / \mathrm{ml}, \mathrm{IF} \\
\mathrm{EM}\end{array}$ & Vector, code: AS- 2300 & Purified lectin & leucoagglutinin \\
\hline Reelin & Mouse & $1: 1000$, IF & $\begin{array}{l}\text { Chemicon (Merck Millipore); } \\
\text { code: MAB5364 }\end{array}$ & $\begin{array}{l}\text { Recombinant reelin } \\
\text { amino acids } \\
164-496\end{array}$ & de Bergeyck et al., 1998 \\
\hline Somatostatin & Mouse & $1: 400$, IF & GeneTex; code: GTX71935 & $\begin{array}{l}\text { Human somatostatin } \\
\text { conjugated to } \\
\text { protein carrier }\end{array}$ & $\begin{array}{l}\text { Labeling pattern as published with } \\
\text { other antibodies }\end{array}$ \\
\hline $\begin{array}{l}\text { Vesicular acetylcholine } \\
\text { transporter }\end{array}$ & Goat, polyclonal & 1:400, IF & $\begin{array}{l}\text { Chemicon (Merck Millipore); } \\
\text { code: ABN100 }\end{array}$ & $\begin{array}{l}\text { Keyhole limpet hemo- } \\
\text { cyanin-conjugated } \\
\text { linear peptide } \\
\text { corresponding to } \\
\text { the C terminus of } \\
\text { rat vesicular acetyl- } \\
\text { choline transporter }\end{array}$ & $\begin{array}{l}\text { Manufacturer's technical } \\
\text { information }\end{array}$ \\
\hline $\begin{array}{l}\text { Vesicular glutamate } \\
\text { transporter } 2\end{array}$ & $\begin{array}{l}\text { Guinea pig, } \\
\text { polyclonal }\end{array}$ & $1: 250$, IF & $\begin{array}{l}\text { Synaptic Systems; code: } \\
135404\end{array}$ & $\begin{array}{l}\text { Recombinant rat } \\
\text { vesicular glutamate } \\
\text { transporter } 2 \text { amino } \\
\text { acids } 510-582\end{array}$ & $\begin{array}{l}\text { Western blot (manufacturer's tech- } \\
\text { nical information) }\end{array}$ \\
\hline WFS1 & Rabbit, polyclonal & $1: 500$, IF & $\begin{array}{l}\text { Proteintech; code: } \\
\text { 11558-1-AP }\end{array}$ & $\begin{array}{l}\text { Recombinant human } \\
\text { WFS1 (wolframin) } \\
\text { amino acids } 1-134\end{array}$ & Takeda et al., 2001 \\
\hline
\end{tabular}

Abbreviations: IF, Immunofluorescence for triton-treated 60 - 80- $\mu \mathrm{m}$-thick sections; EM, electron microscopy (freeze-thaw-treated 60 - 80- $\mu \mathrm{m}$-thick sections); CL, Clarity-processed 500 - $\mu \mathrm{m}$-thick sections.

${ }^{a}$ Information on sources, dilutions (for each procedure used), and specificity of primary antibodies that have not been listed in Viney et al., 2013, their supplementary Table 2, where references are cited.

drated sections were embedded in Durcupan resin (Fluka) and polymerized at $60^{\circ} \mathrm{C}$ for $2 \mathrm{~d}$. Target areas were cut out from the resin-embedded $60-80-\mu \mathrm{m}$-thick sections and re-embedded for ultramicrotome sectioning. Serial 60-nm-thick sections were cut and mounted on single-slot, pioloform-coated copper grids. Sections were observed with a Philips CM100 transmission electron microscope and electron micrographs were acquired with a Gatan UltraScan 1000 CCD camera. All PHALcontaining or enhanced yellow fluorescent protein (EYFP)-containing boutons cut at the section plane were followed in serial sections to locate synaptic junctions.
We identified putative glutamatergic and GABAergic synaptic junctions respectively as type I (often called asymmetrical) and type II (often called symmetrical) based on their fine structure: type I synapses possess a thick postsynaptic density, whereas type II synapses are characterized by a thin postsynaptic density (Gray, 1959). Electron microscopic identification of dendritic profiles in the hippocampus was made according to established criteria (Gulyás et al., 1999; Megías et al., 2001) by following postsynaptic dendrites in $\leq 30$ consecutive sections. Briefly, pyramidal cells of the CA1 region have spiny dendrites and receive type I synapses onto their dendritic spines, whereas their dendritic shafts are 

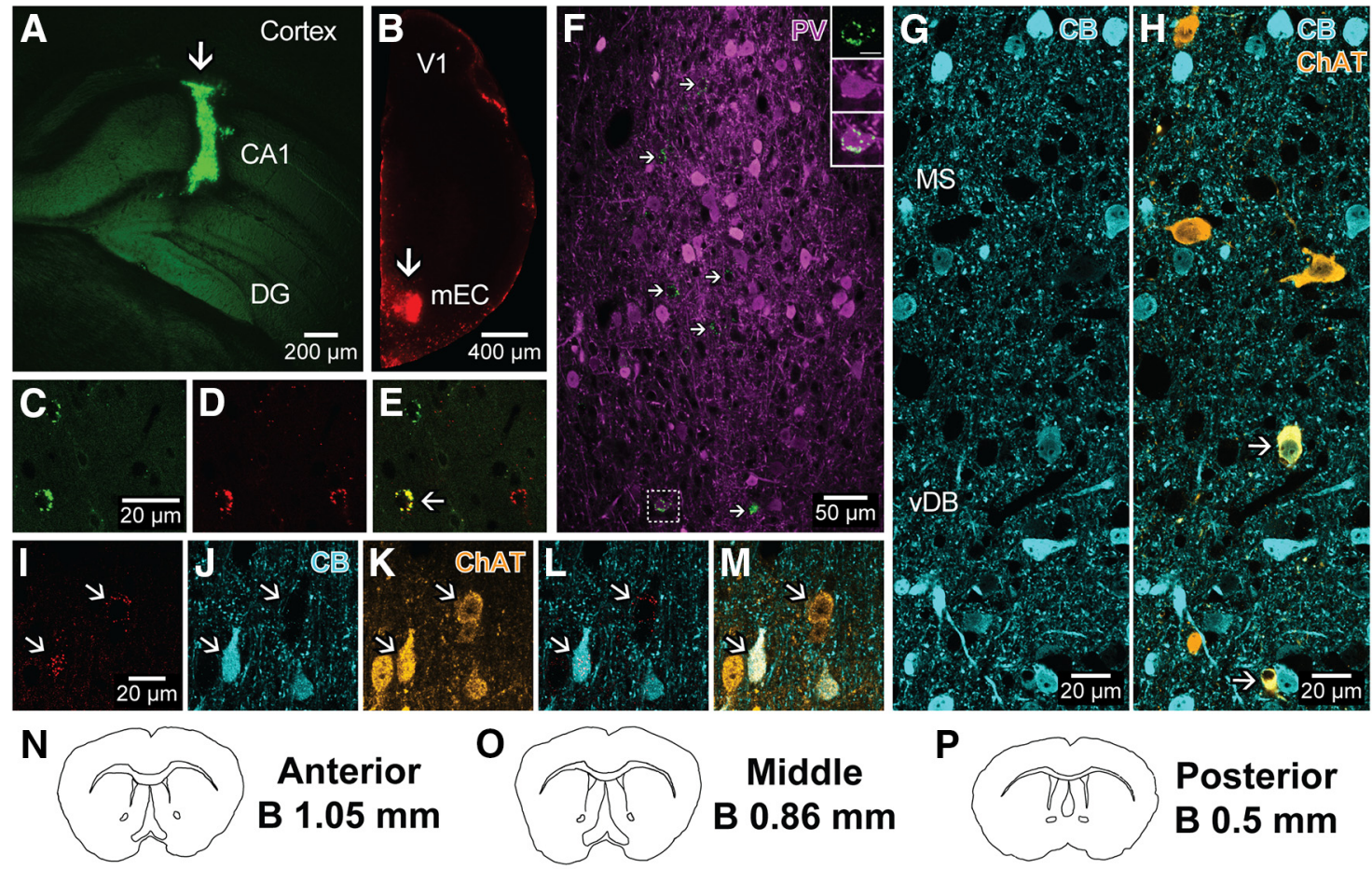

$\mathbf{P}$
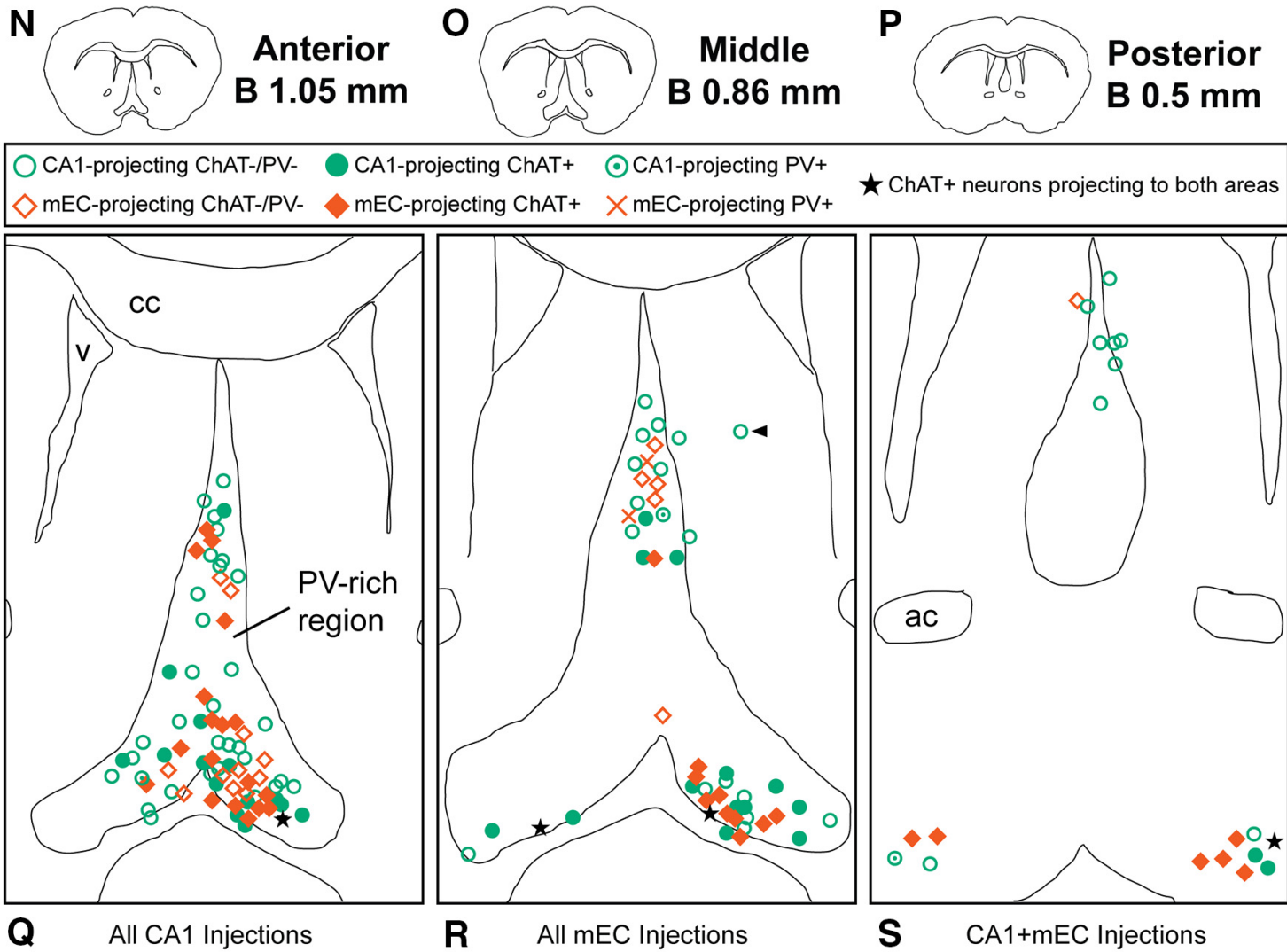

R All mEC Injections

\section{S $\quad \mathrm{CA} 1+\mathrm{mEC}$ Injections}
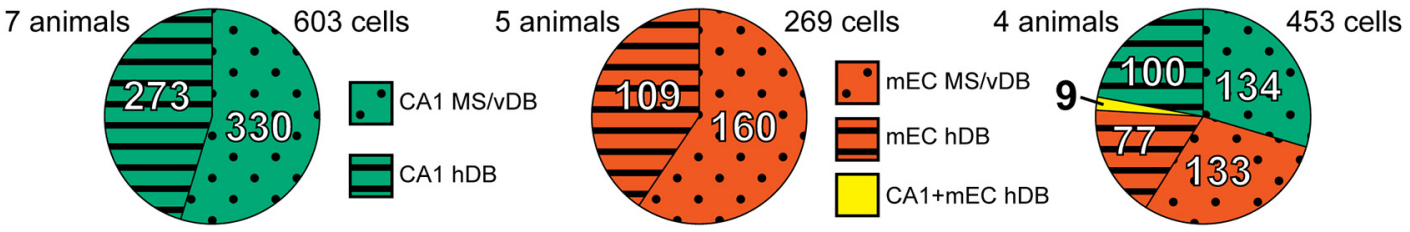

Figure 1. Distribution of retrogradely labeled septal and diagonal band neurons projecting to the hippocampus and/or the $\mathrm{mEC}$. $\boldsymbol{A}$, Green Retrobead injection site (arrow) in the dorsal CA1 region (mouse GU06, coronal section). $\boldsymbol{B}$, Red Retrobead injection site (arrow) in the dorsocaudal mEC (mouse GU07, coronal section). $\boldsymbol{C}-\boldsymbol{E}$, Confocal microscopic images of retrogradely transported green $(\boldsymbol{C})$ or red (D) Retrobeads in somata and their colocalization in an hDB neuron ( $\boldsymbol{E}$, arrow). $\boldsymbol{F}$, A single confocal microscopic optical section of CA1-projecting green Retrobead-labeled neurons (arrows) in the medial septum with immunohistochemistry for PV (magenta). A PV-immunopositive retrogradely labeled neuron (framed area) is shown in the inset (scale bar, $10 \boldsymbol{\mu m}$ ). $\mathbf{G}, \boldsymbol{H}$, Single confocal microscopic images depicting colocalization of CB (cyan) and ChAT (orange) in some (yellow, arrows) but not all neurons in the posterior MS-vDB border. I-M, Two retrogradely labeled $\mathrm{mEC}$-projecting MS/vDB neurons (arrows) are both immunoreactive for $\mathrm{ChAT}(\boldsymbol{K})$ but only one of them is immunoreactive for $C B(\boldsymbol{L})$. $\boldsymbol{N}-\boldsymbol{P}, \mathbf{N e u r o l u c i d a} \mathrm{drawing}$ of the septal and diagonal band area at three rostrocaudal levels marked with positions of retrogradely labeled CA1-projecting (green) and mEC-projecting (red) neurons. Arrowhead in $\mathbf{O}$ points to a (Figure legend continues.) 
innervated almost exclusively by type II synapses. In contrast, the overwhelming majority of hippocampal interneurons have aspiny or sparsely spiny dendrites, which receive both type I and type II synapses (Takács et al., 2012). Freund and Gulyás (1991) reported that these differences in the dendritic synaptic inputs are preserved in the retrosplenial cortex of the rat, where pyramidal cells have spiny dendrites and receive the bulk of their excitatory input through axospinous synapses, whereas the majority of interneurons have varicose and aspiny dendrites. Furthermore, pyramidal cell dendrites in the rat retrosplenial cortex are characterized by many parallel and evenly distributed microtubules, relatively small mitochondria, and cytosolic protein aggregates. In contrast, interneuron dendrites often contain more and larger mitochondria, and free ribosomes (Freund and Gulyás, 1991).

Adobe Photoshop CS3 (Adobe Systems) was used to crop the original images and to apply brightness and contrast adjustments to the whole frame. Adobe Illustrator CS3 was used to add labels and scale bars. Statistical analyses were performed in Matlab (MathWorks). Mean values are reported as mean $\pm \mathrm{SD}$. Median values are reported with interquartile range (IQR).

\section{Results}

Immunohistochemical identification of septal and diagonal band neurons projecting to the dorsal CA1 and/or mEC

All Retrobead injections resulted in restricted labeling in the target regions, the CA1 (Fig. 1A) and the mEC (Fig. 1B), with minimal diffusion to neighboring areas. Both the dorsal CA1 and dorsocaudal mEC injections revealed retrogradely labeled cells in the MS, and the vertical and horizontal diagonal band (vDB, hDB) nuclei ( $n=863$ cells from 8 mice). Injections into the dorsal CA1 labeled 330 neurons ( $n=7$ mice) in the MS and vDB, and 273 neurons ( $n=5$ mice) in the hDB nuclei of both hemispheres. Four mice received injections of differently colored Retrobeads in the two areas. The distribution of labeled cells shows that the hippocampal injection sites received a substantial, but significantly smaller (Wilcoxon signed-rank test, $p<0.05$ ) proportion of their hDB input from the contralateral side (median $=$ 7 cells, IQR $=16)$ compared to the ipsilateral side $($ median $=21$ cells, IQR $=28 ; n=273$ cells from 7 mice). Injections of Retrobeads into the $\mathrm{mEC}$ resulted in fewer labeled neurons than those found to project to CA1 (160 cells in the MS and vDB, and 109 cells in the hDB, $n=5$ animals). Similar to the CA1, unilateral injections into the $\mathrm{mEC}$ resulted in bilateral retrograde labeling in hDB nuclei (Alonso and Köhler, 1984).

The majority of the retrogradely labeled septal cells were medially located in or around the PV-dense region of the MS (Fig. $1 N-P)$. Negligible numbers of retrogradely labeled cells were observed in or beyond the CR-rich layer of the lateral septum (Wei et al., 2012) and all of them were ChAT and PV immunonegative (Fig. 1O). Only 9 of 453 cells projected to both the CA1 and the $\mathrm{mEC}$ as revealed when green and red Retrobeads were colocalized in the same somata (Fig. $1 C-E ; n=4$ mice). All of these doublelabeled neurons were located in the diagonal band nuclei and were immunopositive for ChAT. This does not rule out the existence of multiple area-targeting noncholinergic septal neurons as the two injection sites may not have been at topographically related positions.

\footnotetext{
$\leftarrow$

(Figure legend continued.) retrogradely labeled cell in the lateral septum. The central outlined region indicates the area containing all the PV-immunoreactive somata and labeled processes. Q-S, Proportions and numbers of retrogradely labeled neurons counted in MS/vDB or hDB for all CA1 injections ( $\boldsymbol{Q}$, green) and $\mathrm{mEC}$ injections $(\boldsymbol{R}$, red), which include the double CA1 and $m E$ E injections (S). DG, Dentate gyrus; V1, primary visual cortex; ac, anterior commissure; cc, corpus callosum; $v$, lateral ventricle; $B$, bregma.
}

Table 2. Number and proportion of CA1-projecting or mEC-projecting MS/vDB and hDB neurons tested for ChAT and PV immunoreactivity ${ }^{a}$

\begin{tabular}{|c|c|c|c|c|c|c|c|}
\hline \multirow[b]{2}{*}{ Neurons } & \multirow[b]{2}{*}{ Location } & \multicolumn{3}{|c|}{ All cells tested for ChAT } & \multicolumn{3}{|c|}{$\begin{array}{l}\text { ChAT-negative cells } \\
\text { tested for PV }\end{array}$} \\
\hline & & $N$ & ChAT+ & $(\%)$ & $N$ & PV+ & $(\%)$ \\
\hline \multirow[t]{3}{*}{ CA1-projecting } & MS/vDB & 161 & 57 & (35) & $83^{*}$ & 8 & (10) \\
\hline & hDB & 156 & 97 & (62) & 59 & 3 & (5) \\
\hline & Subtotal & 317 & 154 & (49) & 142 & 11 & (8) \\
\hline \multirow[t]{3}{*}{ mEC-projecting } & MS/vDB & 78 & 46 & (59) & 32 & 3 & (9) \\
\hline & $\mathrm{hDB}$ & 68 & 59 & (87) & 9 & 1 & (11) \\
\hline & Subtotal & 146 & 105 & (72) & 41 & 4 & (10) \\
\hline Total & & 463 & 259 & (56) & 183 & 15 & (8) \\
\hline
\end{tabular}

$a^{a}$ Number and proportion of all retrogradely labeled CA1-projecting or mEC-projecting neurons in MS/vDB and hDB that were tested $(N)$ for ChAT immunoreactivity; the ChAT-immunonegative cells were tested for PV.

*Note that only 83 of 104 ChAT-immunonegative cells were tested for PV.

We tested 463 retrogradely labeled somata for ChAT immunoreactivity (Fig. 1) in the MS and diagonal band nuclei (Table 2). The ChAT-negative, putative GABAergic, and glutamatergic projection cells $(n=183)$ were tested for the calciumbinding protein PV immunoreactivity (Table 2; Fig. $1 F$ ). Overall, $8 \%$ of the ChAT-immunonegative projection neurons showed PV immunoreactivity.

We have also tested 248 ChAT-immunopositive cells for CB immunoreactivity in the MS, vDB, and hDB of three mice, and found that $15 \pm 6 \%$ of ChAT-immunopositive cells express detectable, but often low levels of CB (Fig. $1 G, H$ ). We then tested immunoreactivity for $\mathrm{CB}$ in the retrogradely labeled ChATimmunoreactive neurons and found that 9 of $138(7 \%)$ of the CA1-projecting neurons and 3 of $66(5 \%)$ of the mEC-projecting neurons in the DBC were also immunopositive for CB (Fig. $1 I-M)$. We did not observe any retrogradely labeled CB immunopositive cells that were immunonegative for ChAT. Finally, no retrogradely labeled cell ( $n=58$ tested cells) was immunopositive for CR in any septal or DBC region (for the rat basal forebrain, see Zaborszky et al., 1999). Many of the CR-positive GABAergic neurons project to the supramammilary nucleus in the rat (Leranth et al., 1999).

\section{Septal GABAergic innervation of extrahippocampal cortical areas}

Iontophoretic injections of PHAL into the MS of C57BL6j mice resulted in neuronal labeling along the rostrocaudal septal axis. The ML and DV diffusion of the tracer was minimal; labeling was mostly restricted to the MS and dorsal-most part of the vDB with few labeled neurons observed in the CR-rich layer around the MS. The densest somatic labeling was observed at the center of the injection site, corresponding to the middle of the rostrocaudal extent of the MS in each animal (Fig. 2A).

To trace the axons of the subpopulation of GABAergic septal neurons that express PV, we injected $\mathrm{pAAV}_{2}$-EF1a-DIOEYFP virus into the septum of B6;129P2-Pvalb ${ }^{\text {tm1(cre)Arbr} / J ~}$ mice, resulting in Cre-dependent expression of EYFP. These injections produced restricted somatic labeling at the delivery sites with numerous EYFP-labeled axons projecting dorsally toward the fornix and fimbria (Fig. 2B). They produced few labeled neurons outside the area rich in PV-positive cells of the MS (Fig. 2C). The expression of EYFP was restricted to PVpositive cells, as confirmed by immunohistochemistry for PV (Fig. 2D-F). Accordingly, all the EYFP-immunolabeled somata (Fig. 2D, arrows) were immunoreactive for PV (Fig. 



Figure 2. Anterograde tracer injection sites and immunohistochemical testing of EYFP labeling resulting from AAV injections in the medial septum of PV-Cre mice. $A$, PHAL injection in the MS (mouse TV39, wild type), visualized by wide-field immunofluorescence of PHAL (green). $\boldsymbol{B}$, Three-dimensional Clarity-processed 500- $\mu$ m-thick section image of a PV-Cre mouse (GU31) showing the dorsal projection of the EYFP-immunolabeled axons toward the fimbria/fornix after an AAV injection into the MS. C, Epifluorescence image of an AAV injection into the MS of a PV-Cre mouse (AJ12). $\boldsymbol{D}-\boldsymbol{F}$, Single optical slice images of the injection site shown in $\boldsymbol{C}$ with immunohistochemistry for EYFP ( $\boldsymbol{D}$, green) and PV (E, magenta) showing that all EYFP-immunolabeled neuronal cell bodies (arrows) are immunoreactive for PV (F). Note the variable levels of PV immunoreactivity and lack of viral labeling in some PV-immunopositive neurons ( $\boldsymbol{F}$, asterisks). ac, Anterior commissure; $c c$, corpus callosum; v, lateral ventricle; $\mathrm{LS}$, lateral septum.

$2 E, F)$, but not all PV-immunopositive neurons expressed EYFP (Fig. 2F).

Cortical target regions were delineated by immunohistochemistry for molecular markers. The entorhinal cortex and parasubiculum were marked respectively by strong and weak immunoreactivity for NECAB1. This marker was used to visualize the borders of the entorhinal cortex as well as the border between the presubiculum and parasubiculum (Fig. 3A). Reelin immunolabeling clearly differentiated the entorhinal cortex by dense labeling of stellate cells and interneurons in LII (Fig. 3B). Immunohistochemistry for the insulin-like growth factor binding protein 5 delineated the presubiculum by labeling thalamic axons (Stenvers et al., 1994). Confirming earlier observations of in situ hybridization for Wolfram syndrome 1 homolog (WFS1; Ding, 2013), immunohistochemistry for the protein WFS1 (wolframin) revealed the parasubiculum and LII of the MEC; in both areas it was found in LII pyramidal cells (Takeda et al., 2001).

The hippocampus received much denser medial septal input compared with other cortical areas as observed by both PHAL- labeled and EYFP-labeled axons. Strata radiatum, pyramidale, and oriens were heavily innervated. Few labeled septal axons were observed in the stratum lacunosum-moleculare. Similarly, the molecular layer of the dentate gyrus was innervated less than the granule cell and the polymorphic layers (Fig. $3 C$ ). Consistent anterograde axonal labeling was obtained in the cortical areas described below by both PHAL-labeled projections, presumably including the cholinergic, GABAergic, and glutamatergic axons, and the EYFP-labeled axons from PV-immunopositive GABAergic cells. As discussed below, the major difference between the two methods concerned the types of septal axons labeled.

The main axons of the PHAL-labeled neurons showed more variability in appearance than those originating only from PVexpressing neurons. They could be divided into two groups: relatively thick and smooth main axons with large boutons, and substantially thinner main axons with smaller boutons. We sampled 30 thick/smooth axons branching and forming a total of 128 boutons and all of these boutons tested by confocal microscopy were immunopositive for VGAT ( $n=3$ animals; Fig. $4 A, B$ ). Thus, the 

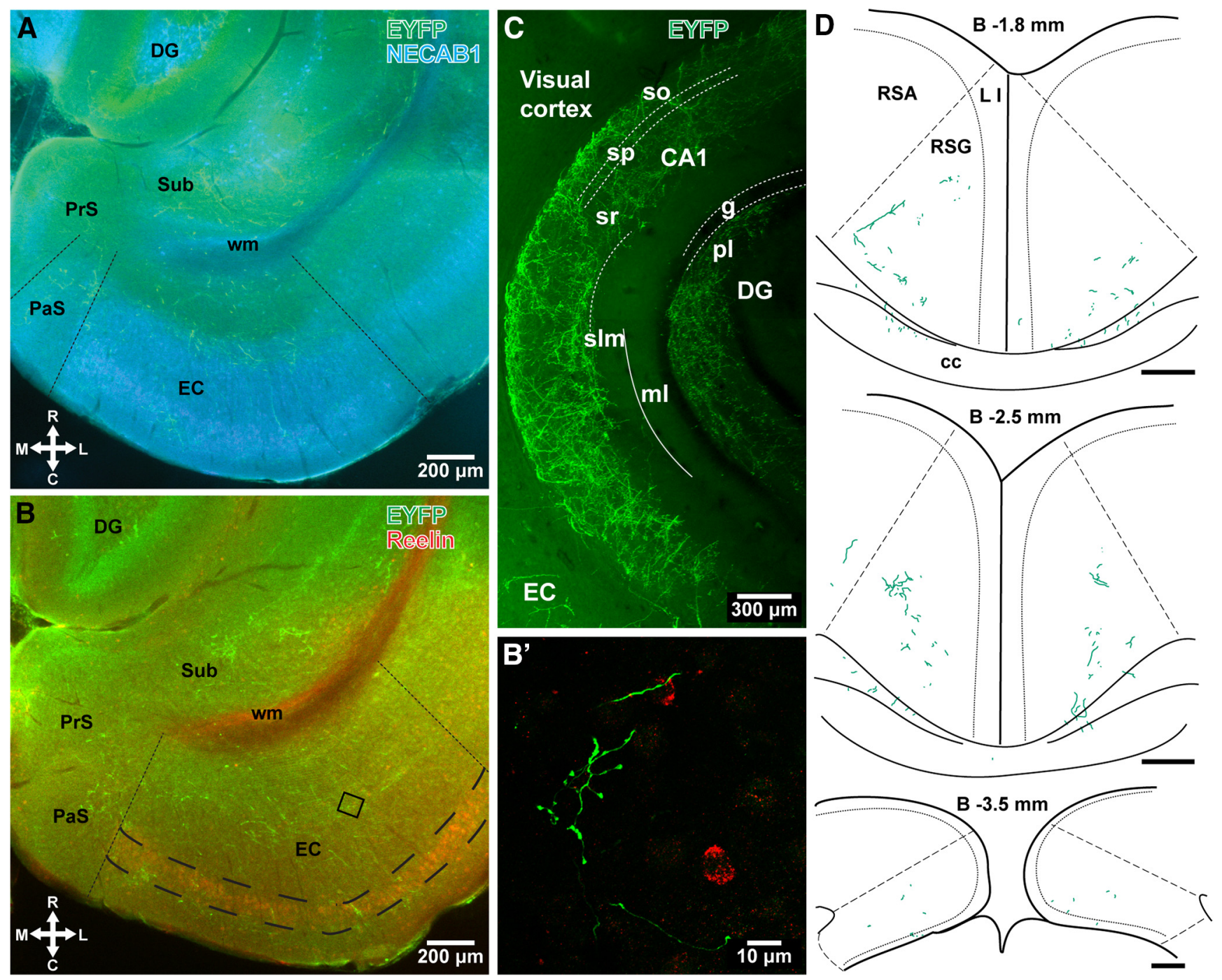

Figure 3. Identification of the target regions of EYFP-labeled septal axons by immunohistochemistry in the hippocampus and extrahippocampal areas. $\boldsymbol{A}, \boldsymbol{B}$, Epifluorescent images showing demarcation (dashed lines) of the parasubiculum (PaS) and entorhinal cortex (EC) by immunohistochemistry for NECAB1 (blue), and the EC by reelin (red) in horizontal brain sections of a PV-Cre mouse superimposed with EYFP-immunofluorescent septal axons (green). The EC and PaS are respectively differentiated by dense and lighter NECAB1 immunoreactivity ( $\boldsymbol{A}$; case GU41s47). Immunolabeling for reelin visualizes mEC LII (large dashed lines) by labeling the stellate cells and interneurons ( $\boldsymbol{B}$; case GU41s20). The white matter (wm) is labeled nonspecifically. $\boldsymbol{B}$ shows, in a confocal microscopic image (maximum intensity projection, $5.14 \mathrm{~m} z$-stack), anterogradely labeled septal axons (green) near reelin-positive interneurons (red, from the framed area in $\boldsymbol{B}$ ). $\boldsymbol{C}$, Differential innervation of layers of the hippocampus by EYFP-labeled medial septal axons; maximum intensity confocal microscopic projection of a 350 - $\mu \mathrm{m}$-thickz-stack of a Clarity-processed thick section. Solid line marks the hippocampal fissure between the CA1 region and dentate gyrus (case GU31hpc). D, Anterogradely labeled septal PV-expressing GABAergic axons at three rostrocaudal levels in the retrosplenial cortex (animal GU42). Dashed lines indicate estimated borders between the agranular (RSA) and granular (RSG) retrosplenial cortices. Scale bars, $200 \mu \mathrm{m}$. Median filter was applied ( $x, y$ : radius, 1 pixel) in C. DG, dentate gyrus; PrS, presubiculum; Sub, subiculum; L I, layer I; so, stratum oriens; sp, stratum pyramidale; sr, stratum radiatum; slm, stratum lacunosummoleculare; $\mathrm{ml}$, molecular layer of the dentate gyrus; $\mathrm{g}$, granule cell layer; $\mathrm{pl}$, polymorphic layer of the dentate gyrus; cc, corpus callosum; $R$, rostral; $C$, caudal; $M$, medial; $L$, lateral; $B$, bregma.

relatively thick and smooth type of main axons originated from GABAergic septal neurons. In contrast, the PHAL-labeled main axons with smaller diameter and boutons were VGAT immunonegative. We have restricted our analysis in the PHAL-labeled material to the axons possessing VGAT-immunoreactive terminals and those that displayed similar boutons. These axons contributed both en passant (Fig. $4 B$ ) and terminal varicosities in all the target regions examined. Only a minority of boutons was in apposition to neuronal somata; the rest presumably innervated dendrites. Target somata were often encapsulated by numerous boutons of the same PHAL-labeled axon (Freund and Buzsáki, 1996), forming a basket-like mesh (Fig. 4C). The same manner of innervation was observed also for the EYFP-immunolabeled axons (Fig. 5A).

The relative density of PHAL-immunolabeled or EYFPimmunolabeled axons with VGAT-immunopositive terminal boutons in the hippocampus as well as in the extrahippocampal cortical areas was similar in the two mouse lines showing similar labeling efficacy. Accordingly, the following conclusions are based on observations of the pooled data. The high density of innervation of the hippocampus proper by GABAergic axons was also present in the subiculum at all levels along the septotemporal axis. The parasubiculum received the densest septal GABAergic projection among other extrahippocampal structures (Fig. $3 A$ ), similar to the dense projections to $\mathrm{mEC}$ LII and layer IV in the rat (Alonso and Köhler, 1984). A lower density of PHALimmunolabeled and EYFP-immunolabeled axons was observed in the presubiculum, $\mathrm{mEC}$, and granular retrosplenial cortex. Together with the hippocampus and parasubiculum, these cortical regions received the majority of septocortical GABAergic input (Fig. $3 A, B$ ). 

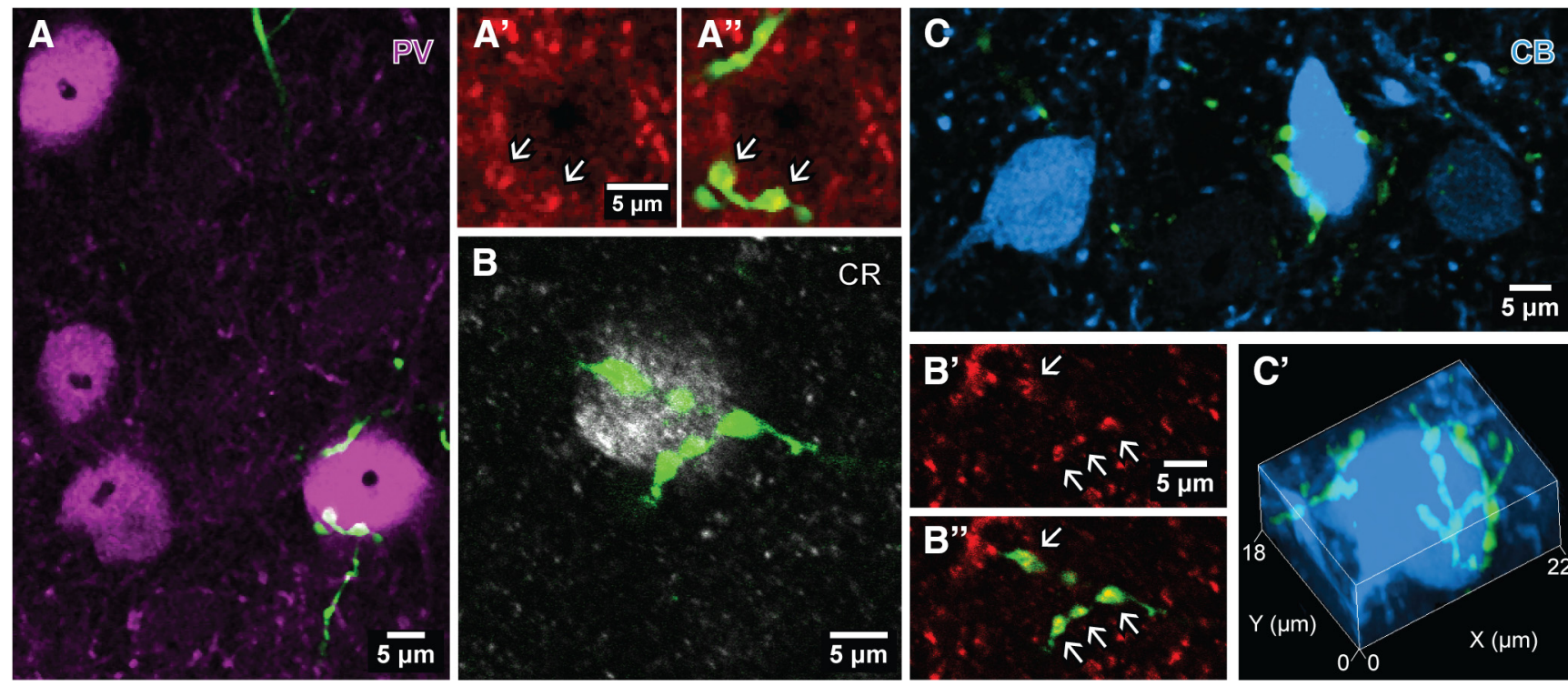

Figure 4. Innervation of different interneurons by PHAL-immunopositive septal axons (green) in the entorhinal cortex. $A$, Confocal image of PV-immunopositive somata (magenta) in layers II/III of the $\mathrm{mEC}$. The soma in the lower right corner is innervated (case AJ04b; single optical section, $0.4 \mu \mathrm{m}$ thick). The boutons (arrows) innervating the soma are VGAT positive ( $\boldsymbol{A}^{\prime}$, red). $\boldsymbol{B}, \boldsymbol{A}$ CR-immunopositive soma (white) in apposition to en passant PHAL-labeled VGAT-positive ( $\boldsymbol{B}^{\prime}$, red) septal boutons (arrows; case AJ10 g) in layers II/III of the lateral entorhinal cortex; single optical section of $0.43 \mu \mathrm{m}$. C, One of the two (B-immunopositive somata (blue) is innervated by PHAL-labeled septal boutons in layer IV of the mEC (case AJ10c; single optical section, $0.49 \mu \mathrm{m}$ thick). This soma is surrounded by boutons of the same axon forming a dense basket-like mesh ( $\boldsymbol{C}^{\prime}$; confocal image stack, $\left.9.27 \mu \mathrm{m}\right)$.

An uneven distribution of anterogradely labeled medial septal GABAergic axons in the entorhinal cortex and retrosplenial cortex probably was due to a topographical organization. Originating from our injection sites, more septal axons were found in the medial and most caudal portions of the entorhinal cortex, with the dorsocaudal $\mathrm{mEC}$ in each animal receiving the most labeled axons and boutons. We have observed relatively few labeled axons in the lateral entorhinal cortex and even fewer in the perirhinal cortex. In the retrosplenial cortex, the densest labeling was found in the caudal and most-medial portions, corresponding to the granular region. The more lateral and dorsal part of the cortex, known as the five-layered, agranular region, received substantially less septal GABAergic input. The density of labeling also decreased in more anterior levels where the retrosplenial cortex fuses with the cingulate cortex.

\section{Diverse types of cortical interneuron innervated by septal GABAergic projections}

We used immunohistochemistry to identify somata and dendrites of the interneurons targeted by anterogradely labeled septal axons. Immunohistochemistry for PV, CB, CR, NECAB1, CCK, $\mathrm{SATB} 1, \mathrm{nNOS}$, or reelin revealed numerous immunopositive target profiles in clear apposition to the boutons immunolabeled for PHAL (Fig. 4) or EYFP (Fig. 5). We have found no differences in the targets of the GABAergic septal axons visualized by immunolabeling for PHAL or EYFP in the entorhinal cortex, compared with the above somatodendritic interneuron markers or marker combinations in $\geq 3$ animals each. Therefore, in other extrahippocampal cortices, we have analyzed only the targets of the EYFPimmunolabeled septal GABAergic axons.

Immunohistochemistry for the aforementioned molecular markers revealed that the diversity of the interneuron targets of EYFP-immunolabeled septal axons observed in the entorhinal cortex (Figs. 4, 5B,F) applied to the subiculum, presubiculum, parasubiculum, and retrosplenial cortex (Table $3 ; n=7$ animals). In each of these extrahippocampal areas, excluding the retro- splenial cortex, interneurons immunopositive for PV, CB, CR, NECAB1, CCK, or reelin were found in clear apposition to septal GABAergic boutons forming putative axosomatic (Fig. $5 A, B$ ) or axodendritic (Fig. 5C-F) synapses. In the retrosplenial cortex, only $\mathrm{PV}, \mathrm{CB}, \mathrm{CR}$, and reelin were found in putative interneuron target somata. Combinations of molecular markers were observed in 28 target neurons. For instance, 47\% of the PVimmunopositive neurons (Fig. 5D) were also immunoreactive for $\mathrm{CB}$ (Fig. $5 E ; n=99$ ) in the depicted area of parasubiculum (Fig. $5 D, E$ ).

The possibility that septal GABAergic axons selectively target certain interneuron types was assessed by following single labeled axons $(n=16)$ in consecutive sections or through $500-\mu \mathrm{m}$-thick Clarity-processed tissue immunoreacted for interneuron molecular markers. The limited number of antibodies and fluorophores that could be used in the same section allowed the visualization of only few of the targets of each single axon. Nevertheless, we often observed a single labeled axon innervating target cells labeled for the same molecule, such as PV $(n=4$ axons, $2-3$ cells each; Fig. 5A), or NECAB1 and CCK $(n=2$ axons, 2 and 4 cells). These septal axons with an apparent target selectivity also formed boutons around cellular profiles that were not labeled by any of the tested markers, including the molecule that was found in the nearby targeted cells (Fig. 5A, B). Thus, we have not observed strict target cell-type selectivity by labeled septal axons. On the contrary, nine single septal axons were in apposition to profiles that were immunopositive for different set of molecular markers. For example, boutons of a single septal axon in the subiculum were in apposition to an interneuron immunopositive for PV and SATB1, as well as to a nearby NECAB1immunopositive, but $\mathrm{PV}$-immunonegative, neuron that was also immunoreactive for SATB1. In another case, a single EYFP-immunolabeled axon in subiculum innervated a soma immunoreactive for CCK and NECAB1 as well as another NECAB1immunopositive but CCK-immunonegative neuron (Fig. 5G). 

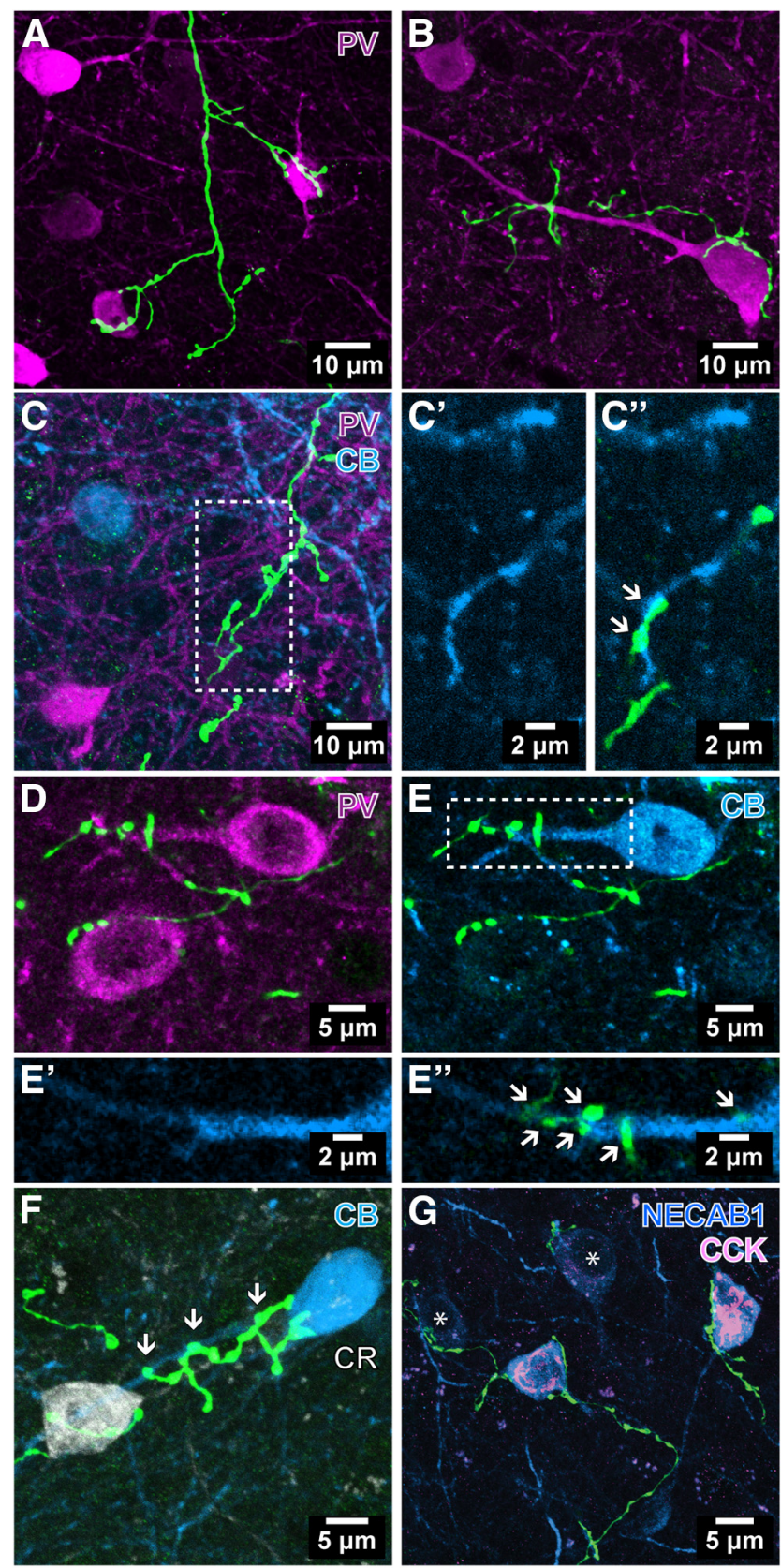

Figure 5. Innervation of interneurons by EYFP-labeled septal axons (green) in extrahippocampal cortical areas of PV-Cre mice. $\boldsymbol{A}, \boldsymbol{B}$, Innervation of two PV-immunopositive (magenta) somata by the same axon in presubiculum ( $\boldsymbol{A}$; case AJ14ab), and another neuron in deep layers of the lateral entorhinal cortex ( $\boldsymbol{B}$; case AJ13a). $\boldsymbol{C}$, Juxtaposition of septal boutons with a CBimmunopositive (blue) dendritic profile in presubiculum; single optical slices (thickness: $1 \mu \mathrm{m}$ ) are enlarged $\left(\boldsymbol{C}^{\prime}\right)$ and overlaid with the labeled axon $\left(\boldsymbol{C}^{\prime \prime}\right)$ showing putative axodendritic contacts (arrows; case AJ14j). D, E, Two separate labeled axons in parasubiculum innervate two target cells immunopositive for PV ( $\boldsymbol{D}$, magenta). The upper neuron is also immunoreactive for $C B(E$, blue). A single optical slice (thickness: $0.36 \mu \mathrm{m})$ of the proximal dendrite of this cell (framed) is shown in $\boldsymbol{E}^{\prime}$ and overlaid with the septal axons $\left(\boldsymbol{E}^{\prime \prime}\right)$, demonstrating putative axodendritic contacts (arrows, case GU41jk). F, A CR-immunopositive (white) and a (Bimmunopositive (blue) soma are innervated by separate labeled axons in the lateral entorhinal cortex. Arrows point to boutons overlapping with the dendrite of the $(B$-immunopositive neuron (case AJ12eeff). G, Four NECAB1-immunopositive (blue) neurons are targeted by septal axons in the dorsal subiculum (case AJ13s14). Two targets strongly immunopositive for NECAB1 are also positive for CCK (pink), whereas weakly NECAB1-immunoreactive somata are CCK immunonegative (asterisks). One labeled septal axon (left) innervates both kinds of cells. Median filter was applied ( $x, y$ : radius, 1 pixel) in $\boldsymbol{A}$ and $\boldsymbol{B}$. Maximum intensity projections of confocal image stacks: $\boldsymbol{A}, 21.58 \mu \mathrm{m} ; \boldsymbol{B}, 12.07 \mu \mathrm{m} ; \boldsymbol{C}, 22 \mu \mathrm{m} ; \boldsymbol{D}$ and $\boldsymbol{E}, 2.49 \mu \mathrm{m} ; \boldsymbol{F}$, $10.38 \mu \mathrm{m} ; \boldsymbol{G}, 8.19 \mu \mathrm{m}$.
Table 3. Molecular cell markers and their combinations found in septal target neurons ${ }^{a}$

\begin{tabular}{|c|c|c|c|c|c|c|}
\hline & Subiculum & Presubiculum & Parasubiculum & $\begin{array}{l}\text { Retrosplenial } \\
\text { cortex }\end{array}$ & $\begin{array}{l}\text { Lateral } \\
\text { entorhinal } \\
\text { cortex }\end{array}$ & $\mathrm{mEC}$ \\
\hline PV & + & + & + & + & + & + \\
\hline CB & + & + & + & + & + & + \\
\hline$C R$ & + & + & + & + & + & + \\
\hline NECAB1 & + & + & + & n.o. & + & + \\
\hline CCK & + & + & + & n.o. & + & + \\
\hline Reelin & + & + & + & + & + & + \\
\hline nNOS & + & n.o. & + & n.o. & n.o. & + \\
\hline$P V+C B$ & + & + & + & n.o. & n.t. & + \\
\hline PV + SATB1 & + & + & + & + & n.t. & n.o. \\
\hline$C B+$ reelin & + & n.o. & n.o. & + & n.o. & n.o. \\
\hline $\mathrm{CB}+\mathrm{nNOS}$ & + & n.t. & n.t. & n.o. & n.t. & n.t. \\
\hline $\mathrm{NECAB1}+\mathrm{CCK}$ & + & n.o. & + & n.t. & n.t. & n.t. \\
\hline $\begin{array}{c}\text { NECAB1 + } \\
\text { SATB1 }\end{array}$ & + & n.t. & + & n.t. & n.t. & n.t. \\
\hline $\begin{array}{l}\mathrm{PV}+\text { SATB1 } \\
\text { nNOS }\end{array}$ & + & n.t. & n.t. & n.o. & n.t. & n.o. \\
\hline
\end{tabular}

${ }^{a}$ Immunohistochemical molecular markers or marker combinations found in interneurons in clear apposition to the EYFP-immunolabeled septal GABAergic boutons in each extrahippocampal cortical area. +, Observed; n.o., not observed when searched in $>4$ sections; n.t., not tested.

\section{Septal GABAergic projections in the $\mathrm{mEC}$, retrosplenial} cortex, and the CA1 innervate interneurons

We have tested the postsynaptic targets of septal axons in the cerebral cortex by two methods. First, we immunolabeled pyramidal cells in LII of the mEC by immunohistochemistry for WFS1 and CB, and stellate cells for reelin. At different rostrocaudal levels in LII of the entorhinal cortex, we followed single labeled GABAergic axons of PV-expressing septal neurons immunolabeled for EYFP and searched for putative target profiles immunopositive for WFS1, CB, or reelin ( $n=4$ animals). No labeled septal boutons were found in clear apposition to WFS1/ CB-immunopositive somata or proximal dendrites or reelinpositive stellate cell somata (Fig. 6A, asterisks). Some other smaller reelin-positive somata were found in apposition to the EYFP-labeled axonal varicosities in all layers of the MEC (Fig. 6), which are likely to be interneurons (Chin et al., 2007).

Second, to investigate the range of synaptic targets, we analyzed with an electron microscope PHAL-labeled (Fig. $7 A, C-E$ ) or EYFP-expressing (Fig. 7B) axonal boutons. They formed type II synapses and targeted mostly dendritic shafts in the CA1 region (Fig. $7 A, B$ ) and retrosplenial cortex (Fig. 7C-E). We identified a total of 33 synaptic junctions formed by PHAL-immunolabeled boutons in the strata radiatum, pyramidale, lacunosummoleculare, and oriens of CA1 ( $n=2$ animals). One-third of the synapses were axosomatic and the remaining were axodendritic (Fig. 7A). All the postsynaptic profiles were identified as interneuronal, as they received type I synapses from unlabeled boutons and no spines were observed originating from the dendritic shafts. We also examined the synaptic targets of PV-expressing septal GABAergic neurons in the stratum pyramidale of CA1. Of the 15 axodendritic and 5 axosomatic (Fig. $7 B$ ) type II synapses identified, all belonged to interneurons ( $n=2$ animals). Hence, in these samples, no labeled boutons that formed type II junctions and originated from identified or presumed GABAergic medial septal axons made synapses with pyramidal cells in the CA1 region. Finally, we analyzed the superficial and deep layers of the granular retrosplenial cortex and recorded in serial sections 47 type II synaptic junctions formed by PHAL-immunolabeled boutons ( $n=2$ animals). We identified 18 postsynaptic dendritic 
shafts (Fig. 7C) and 8 somata (Fig. 7D) as interneurons (93\% of identified targets) based on the criteria applied to the hippocampus above and as described previously (Freund and Gulyás, 1991). Two postsynaptic dendrites (7\% of identified targets) probably belonged to pyramidal cells. One small dendrite was an oblique side branch of a thick, radially oriented dendrite that had the characteristics of a pyramidal cell apical dendrite receiving only type II synapses $(n=3)$. An additional small dendritic shaft was also identified as originating from a pyramidal cell. The dendrite from this cell, similar to the first dendrite, had small electrondense bodies associated with the endoplasmic reticulum, which are characteristic of pyramidal cells in the hippocampus. The remaining 19 synaptic junctions ( $40 \%$ of all targets) were established with small dendritic profiles, which did not receive other synaptic input within the section series we studied. Only one of them emitted a spine (Fig. 7E). The origin of these dendritic targets could not be identified; they may belong to interneurons or pyramidal cells. Based on the identified postsynaptic elements, we conclude that the majority of septal GABAergic boutons target interneurons.

The anterograde labeling of axons using PHAL is not selective for any transmitter phenotype. We have therefore tested the area of the retrosplenial cortex in two animals from which the sample for electron microscopy was taken for the presence of vesicular glutamate transporter 2 (VGluT2) and vesicular acetylcholine transporter (VAChT). We sampled 14 PHAL-labeled axonal branches in the granular retrosplenial area from both animals and tested their boutons in a neighboring section, which was analyzed by both light and electron microscopy. None of the 14 axonal branches was immunopositive for VGluT2 or VAChT, indicating that the boutons sampled for electron microscopy did not originate from glutamatergic or cholinergic medial septal neurons. Four of the axons were traced back to the aforementioned relatively thick and smooth type of main axons that often give rise to VGAT-immunopositive boutons. The remaining axons could not be traced back to a main axon.

\section{Discussion}

We have revealed septal and DBC GABAergic innervation of hippocampal and extrahippocampal cortices in the mouse, and have identified diverse types of GABAergic interneuronal targets. Individual septal axons showed no strict selectivity for any cell type with the molecular markers studied here. In the mouse, unlike in the rat (Celio and Norman, 1985; Chang and Kuo, 1991; Smith et al., 1994; Kiss et al., 1997), the parallel cholinergic innervation of the hippocampus and mEC originates from both calbindinpositive and calbindin-negative neurons. Septal inactivation, af- fecting ascending projections to the cortex and descending projections to subcortical structures, abolishes spatial periodicity of grid cell activity fields, but spares hippocampal place cell activity fields and other spatially modulated patterns (Brandon et al., 2011, 2014; Koenig et al., 2011; Wang et al., 2015). Accordingly, the septal GABAergic innervation may contribute to spatial coding of grid cells by coordinating theta-rhythmic firing of local GABAergic interneurons.

\section{Target selectivity of septal GABAergic projections}

Electron microscopy of septal GABAergic terminals in CA1 of the mouse showed that, as in the rat (Freund and Antal, 1988), interneurons are the exclusive synaptic targets. In contrast to a recent retrograde trans-synaptic tracing study based on CaMKII expression in mouse (Sun et al., 2014), we did not observe pyramidal cell targets of septal GABAergic neurons, which may be due to our anterograde tracers not labeling potential pyramidal celltargeting axons. Alternatively, the suggested GABAergic neurons presynaptic to pyramidal cells may not be GABAergic (Sun et al., 2014). Some PV-immunopositive cortical neurons express 

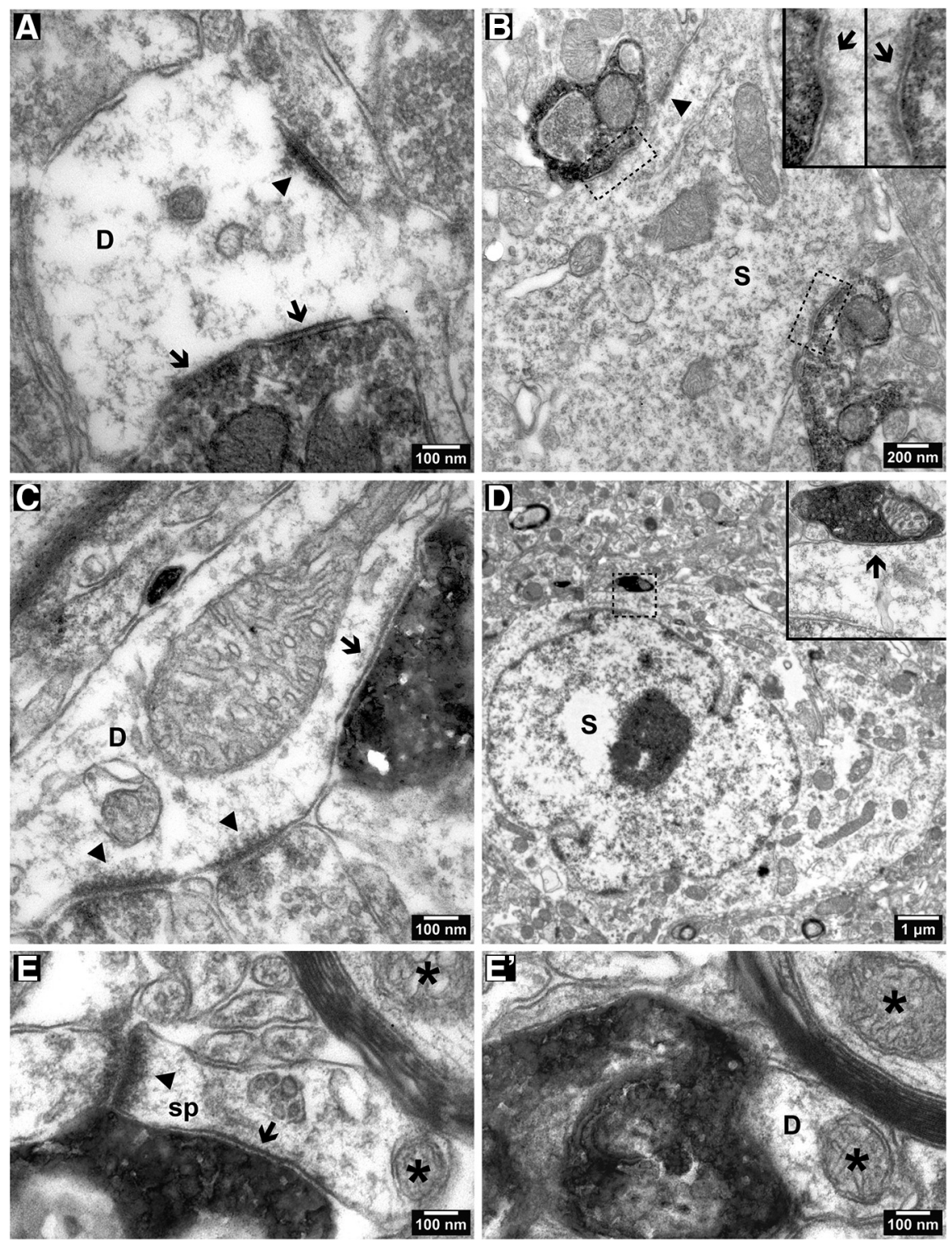

Figure 7. $\boldsymbol{A}-\boldsymbol{E}^{\prime}$, Electron micrographs of synapses (arrows) formed by immunoperoxidase-labeled medial septal boutons in the CA1 region $(\boldsymbol{A}, \boldsymbol{B})$ and retrosplenial cortex $\left(\boldsymbol{C}-\boldsymbol{E}^{\prime}\right)$. $\boldsymbol{A}$, A PHAL-immunolabeled bouton forms two type Il synaptic junctions (arrows) with a dendrite, which receives a type I synapse (arrowhead). $\boldsymbol{B}$, Two EYFP-immunolabeled boutons make synapses (framed, enlarged in the insets) with an interneuron soma in stratum pyramidale of a PV-Cre mouse. The target soma also receives a type I synapse (arrowhead). C, A PHAL-immunolabeled bouton in the retrosplenial cortex forms a type ll synapse (arrow) with a dendrite that also receives type I synapses (arrowheads). D, A PHAL-immunolabeled bouton forms an axosomatic synapse (framed, enlarged in the inset) in the retrosplenial cortex. $\boldsymbol{E}, \boldsymbol{E}^{\prime}$, Nonconsecutive serial sections showing a PHAL-immunolabeled bouton forming a type II synapse (arrow) with a spiny dendrite in the retrosplenial cortex. The spine receives a type I synapse (E, arrowhead). Asterisks mark the same mitochondria. D, Dendritic shaft; S, soma; sp, dendritic spine.

CaMKII (Watakabe et al., 2015), and PV-positive neurons are GABAergic in the hippocampus. In the retrosplenial cortex, most synaptic targets were also interneurons, although the cellular origin of many small dendritic postsynaptic targets could not be determined (Freund and Gulyás, 1991). The two synaptic junctions on retrosplenial pyramidal cell dendrites suggest that, in the mouse, GABAergic medial septal neurons provide a limited innervation of pyramidal cells, as seen in the basolateral amygdala (McDonald et al., 2011).

The overall projection patterns of septal axons in the mouse were similar to earlier observations in rats (Nyakas et al., 1987; Freund and Gulyás, 1991). Target interneuron somata and dendrites were immunopositive for a wide range of molecular interneuron cell-type markers. Unlike in the CA1 (Somogyi, 2010), the relationships between molecular markers and interneuron types in extrahippocampal areas remain mostly undefined, awaiting visualization of their axons and their in vivo firing patterns. Based on neurochemical characterization of single neocortical interneurons with visualized axons, some septally innervated interneurons may prove to be putative PV-immunoreactive or CCK-immunoreactive basket cells, PV-immunoreactive and/or CB-immunoreactive axo-axonic cells, and somatostatin-immunopositive dendrite-innervating interneurons (Cauli et al., 1997; Markram et al., 2004; Xue et al., 2014). In the subiculum, most, but not all, PV-immunoreactive target somata expressed SATB1. Although the distribution of SATB1 is different in the subiculum and CA1, distinct combinations of PV, SATB1, and somatostatin may eventually define different types of subicular PV interneurons (Viney et al., 2013).

Two major populations of mEC principal cells in LII, pyramidal cells, and stellate cells differ in their dendritic arborization (Germroth et al., 1989; Lingenhöhl and Finch, 1991; Alonso and Klink, 1993), electrical properties (Klink and Alonso, 1997; Canto and Witter, 2012), and projections (Varga et al., 2010; Kitamura et al., 2014). Grid cells may include one or both groups (Hafting et al., 2005; Pastoll et al., 2013; Tang et al., 2014). Although we have not observed septal GABAergic boutons apposed to principal cells, we cannot rule out innervation of their distal dendrites. However, this is unlikely, as selective activation of the septal GABAergic input in a slice preparation leads to monosynaptic GABAergic IPSPs in only $1.5 \%$ of nonstellate principal neurons and never in stellate cells, compared with $>60 \%$ of interneurons (Gonzalez-Sulser et al., 2014). Accordingly, almost all septal GABAergic input in the $\mathrm{mEC}$ is received by different types of GABAergic interneurons. These may include the CCK-immunoreactive interneurons shown here, which correspond to the CB1Rexpressing basket cells innervating entorhinal principal cells that do not form part of the perforant path (Varga et al., 2010). In contrast, it is likely that PV-immunopositive basket cells and other interneurons contribute to the disynaptic inhibition between LII stellate cells (Couey et al., 2013). Based on the diversity of target GABAergic interneuron types in all the observed regions, similar septal connections may exist in the presubiculum and parasubiculum, which also contain grid cells along with head-direction cells (Dumont and Taube, 2015). The GABAergic septal DBC neurons, shown here innervating all extrahippocampal areas in the mouse, may coordinate interareal activity between functionally related areas. It remains to be determined 
whether single septal neurons innervate one or many functionally related target areas (see below). Defining the target cell selectivity of individual septal neurons would also require a full labeling of their axons and the identification of their target interneurons, which is difficult to achieve. Our observation that individual septal GABAergic axons innervate cortical interneurons expressing different combinations of molecules predicts that septal neurons act through a range of interneuron types. But we also observed single septal axons, for example, contacting only NECAB1/CCK target interneurons within a limited area. This indicates that neither strict interneuron type specificity nor randomness applies to target cell selectivity of GABAergic septal projections.

\section{Roles of septal GABAergic neurons in network activity and theta oscillations}

The firing of theta-rhythmic septal GABAergic neurons was proposed to lead theta oscillations in the hippocampus (Hangya et al., 2009), suggesting rhythmic inhibition of hippocampal interneurons, resulting in disinhibition of principal cells in phase with the septal neuron firing (Freund and Antal, 1988; Tóth et al., 1997; Vertes and Kocsis, 1997). However, the preferential firing of theta-coupled neurons in both the MS and hippocampus occurs at virtually all theta phases (Petsche et al., 1962; Vinogradova, 1995; Dragoi et al., 1999; Borhegyi et al., 2004). During 100-150 ms theta cycles, maximal cofiring of GABAergic neurons and their synaptic targets may occur in phase, while during simultaneous faster 10-20 ms gamma cycles they may fire out of phase (Belluscio et al., 2012; Kim et al., 2015). The preferred firing phases of single septal GABAergic neurons and their target interneurons are unknown. In the hippocampus, the maximal firing probability of pyramidal cells during the theta cycle (Mizuseki et al., 2009) is in phase with the maximal firing of presynaptic GABAergic PV-expressing bistratified and orienslacunosum moleculare cells (Katona et al., 2014). Moreover, bistratified and basket interneurons also discharge strongly during $\sim 100$-ms-duration sharp-wave-associated ripple oscillations (Lapray et al., 2012; Varga et al., 2012; Katona et al., 2014), the highest firing probability of their target pyramidal cell population. Some rhythmic septohippocampal neurons also fire during sharp-wave-associated ripples (Viney et al., 2013), while many MS neurons are silent (Dragoi et al., 1999), but the identity of the synaptic target cells of both populations is unknown. Accordingly, until the link between the firing of single septal GABAergic neurons and their target cells is discovered, both in and out of phase firing remain possible on a theta cycle time scale, and the gamma frequency discharge of single septal GABAergic neurons and their target cells may contribute to cortical gamma oscillations (Duque et al., 2000; Hassani et al., 2009; Kim et al., 2015). Furthermore, septal GABAergic inputs may synchronize neuronal populations not only within but also between cortical and subcortical areas (Vertes and Kocsis, 1997; Jones and Wilson, 2005). If single septal GABAergic neurons innervate $>1$ cortical area, they would act through their target interneurons to synchronize their activity. The dynamic theta phase coupling between cortical areas is of fundamental behavioral importance in mammals, including humans (Linkenkaer-Hansen et al., 2005; Guitart-Masip et al., 2013). If each cortical area receives septal GABAergic input from distinct sets of neurons, then these are probably synchronized by their brainstem and hypothalamic inputs, or by local synaptic networks within the septum (Borhegyi et al., 2004; Leão et al., 2015).

The firing of hippocampal interneurons contains spatial information, as firing rate indicates the position of the rat (Hangya et al., 2010), or theta phase precession during the progression through the place field (Maurer et al., 2006). As interneuron firing fields may be inversely related to those of pyramidal cells (Ego-Stengel and Wilson, 2007; Hangya et al., 2010), the septal GABAergic innervation may contribute to the modulation of interneuron firing fields and consequently those of pyramidal cells. Similarly, the septal coordination of the theta rhythm in the mEC could contribute to firing fields of local interneurons complementing those of grid cells.

The extensive septal and DBC GABAergic innervation of cortical interneurons shows a similar organization throughout the temporal cortex. Retrograde axonal labeling revealing septal projection neurons showed a low proportion of PV-immunopositive cells. In addition to this rhythmic firing and hippocampal thetacoupled subpopulation, there are other theta-rhythmic GABAergic neurons in the basal forebrain of rats (Simon et al., 2006). Diverse types of septal GABAergic cells and their innervated interneurons may act with different temporal dynamics (Borhegyi et al., 2004). Selective septal GABAergic input may modulate the theta phase preference of target interneuron types, contributing to theta-related firing dynamics as occur locally in the hippocampus (Somogyi et al., 2014).

\section{References}

Alonso A, Klink R (1993) Differential electroresponsiveness of stellate and pyramidal-like cells of medial entorhinal cortex layer II. J Neurophysiol 70:128-143. Medline

Alonso A, Köhler C (1984) A study of the reciprocal connections between the septum and the entorhinal area using anterograde and retrograde axonal transport methods in the rat brain. J Comp Neurol 225:327-343. CrossRef Medline

Apps R, Ruigrok TJ (2007) A fluorescence-based double retrograde tracer strategy for charting central neuronal connections. Nat Protoc 2:18621868. CrossRef Medline

Belluscio MA, Mizuseki K, Schmidt R, Kempter R, Buzsáki G (2012) Crossfrequency phase-phase coupling between theta and gamma oscillations in the hippocampus. J Neurosci 32:423-435. CrossRef Medline

Borhegyi Z, Varga V, Szilágyi N, Fabo D, Freund TF (2004) Phase segregation of medial septal GABAergic neurons during hippocampal theta activity. J Neurosci 24:8470-8479. CrossRef Medline

Brandon MP, Bogaard AR, Libby CP, Connerney MA, Gupta K, Hasselmo ME (2011) Reduction of theta rhythm dissociates grid cell spatial periodicity from directional tuning. Science 332:595-599. CrossRef Medline

Brandon MP, Koenig J, Leutgeb JK, Leutgeb S (2014) New and distinct hippocampal place codes are generated in a new environment during septal inactivation. Neuron 82:789-796. CrossRef Medline

Canto CB, Witter MP (2012) Cellular properties of principal neurons in the rat entorhinal cortex. II. The medial entorhinal cortex. Hippocampus 22:1277-1299. CrossRef Medline

Cauli B, Audinat E, Lambolez B, Angulo MC, Ropert N, Tsuzuki K, Hestrin S, Rossier J (1997) Molecular and physiological diversity of cortical nonpyramidal cells. J Neurosci 17:3894-3906. Medline

Celio MR, Norman AW (1985) Nucleus basalis Meynert neurons contain the vitamin D-induced calcium-binding protein (Calbindin-D 28k). Anat Embryol (Berl) 173:143-148. CrossRef Medline

Chang HT, Kuo H (1991) Calcium-binding protein (calbindin D-28k) immunoreactive neurons in the basal forebrain of the monkey and the rat: relationship with the cholinergic neurons. Adv Exp Med Biol 295:119_ 126. CrossRef Medline

Chin J, Massaro CM, Palop JJ, Thwin MT, Yu GQ, Bien-Ly N, Bender A, Mucke L (2007) Reelin depletion in the entorhinal cortex of human amyloid precursor protein transgenic mice and humans with Alzheimer's disease. J Neurosci 27:2727-2733. CrossRef Medline

Chrobak JJ, Stackman RW, Walsh TJ (1989) Intraseptal administration of muscimol produces dose-dependent memory impairments in the rat. Behav Neural Biol 52:357-369. CrossRef Medline

Chung K, Wallace J, Kim SY, Kalyanasundaram S, Andalman AS, Davidson TJ, Mirzabekov JJ, Zalocusky KA, Mattis J, Denisin AK, Pak S, Bernstein H, Ramakrishnan C, Grosenick L, Gradinaru V, Deisseroth K (2013) 
Structural and molecular interrogation of intact biological systems. Nature 497:332-337. CrossRef Medline

Colom LV, Castaneda MT, Reyna T, Hernandez S, Garrido-Sanabria E (2005) Characterization of medial septal glutamatergic neurons and their projection to the hippocampus. Synapse 58:151-164. CrossRef Medline

Couey JJ, Witoelar A, Zhang SJ, Zheng K, Ye J, Dunn B, Czajkowski R, Moser MB, Moser EI, Roudi Y, Witter MP (2013) Recurrent inhibitory circuitry as a mechanism for grid formation. Nat Neurosci 16:318-324. CrossRef Medline

de Bergeyck V, Naerhuyzen B, Goffinet AM, Lambert de Rouvroit C (1998) A panel of monoclonal antibodies against reelin, the extracellular matrix protein defective in reeler mutant mice. J Neurosci Methods 82:17-24. CrossRef Medline

Ding SL (2013) Comparative anatomy of the prosubiculum, subiculum, presubiculum, postsubiculum, and parasubiculum in human, monkey, and rodent. J Comp Neurol 521:4145-4162. CrossRef Medline

Dragoi G, Carpi D, Recce M, Csicsvari J, Buzsáki G (1999) Interactions between hippocampus and medial septum during sharp waves and theta oscillation in the behaving rat. J Neurosci 19:6191-6199. Medline

Dumont JR, Taube JS (2015) Chapter 5-The neural correlates of navigation beyond the hippocampus. In: Progress in brain research: the connected hippocampus (O’Mara S, Tsanov M, eds), pp 83-102. Amsterdam: Elsevier.

Duque A, Balatoni B, Detari L, Zaborszky L (2000) EEG correlation of the discharge properties of identified neurons in the basal forebrain. J Neurophysiol 84:1627-1635. Medline

Dwyer TA, Servatius RJ, Pang KC (2007) Noncholinergic lesions of the medial septum impair sequential learning of different spatial locations. J Neurosci 27:299-303. CrossRef Medline

Ego-Stengel V, Wilson MA (2007) Spatial selectivity and theta phase precession in CA1 interneurons. Hippocampus 17:161-174. CrossRef Medline

Fernandez FR, Malerba P, Bressloff PC, White JA (2013) Entorhinal stellate cells show preferred spike phase-locking to theta inputs that is enhanced by correlations in synaptic activity. J Neurosci 33:6027-6040. CrossRef Medline

Freund TF, Antal M (1988) GABA-containing neurons in the septum control inhibitory interneurons in the hippocampus. Nature 336:170-173. CrossRef Medline

Freund TF, Buzsáki G (1996) Interneurons of the hippocampus. Hippocampus 6:347-470. Medline

Freund TF, Gulyás AI (1991) GABAergic interneurons containing calbindin D28K or somatostatin are major targets of GABAergic basal forebrain afferents in the rat neocortex. J Comp Neurol 314:187-199. CrossRef Medline

Gerfen CR, Sawchenko PE (1984) An anterograde neuroanatomical tracing method that shows the detailed morphology of neurons, their axons and terminals: immunohistochemical localization of an axonally transported plant lectin, Phaseolus vulgaris Leucoagglutinin (PHA-L). Brain Res 290: 219-238. CrossRef Medline

Germroth P, Schwerdtfeger WK, Buhl EH (1989) Morphology of identified entorhinal neurons projecting to the hippocampus. A light microscopical study combining retrograde tracing and intracellular injection. Neuroscience 30:683-691. CrossRef Medline

Givens B, Olton DS (1994) Local modulation of basal forebrain: effects on working and reference memory. J Neurosci 14:3578-3587. Medline

Gonzalez-Sulser A, Parthier D, Candela A, McClure C, Pastoll H, Garden D, Sürmeli G, Nolan MF (2014) GABAergic projections from the medial septum selectively inhibit interneurons in the medial entorhinal cortex. J Neurosci 34:16739-16743. CrossRef Medline

Gray EG (1959) Axo-somatic and axo-dendritic synapses of the cerebral cortex: an electron microscope study. J Anat 93:420-433. Medline

Guitart-Masip M, Barnes GR, Horner A, Bauer M, Dolan RJ, Duzel E (2013) Synchronization of medial temporal lobe and prefrontal rhythms in human decision making. J Neurosci 33:442-451. CrossRef Medline

Gulyás AI, Görcs TJ, Freund TF (1990) Innervation of different peptidecontaining neurons in the hippocampus by GABAergic septal afferents. Neuroscience 37:31-44. CrossRef Medline

Gulyás AI, Megías M, Emri Z, Freund TF (1999) Total number and ratio of excitatory and inhibitory synapses converging onto single interneurons of different types in the CA1 area of the rat hippocampus. J Neurosci 19: 10082-10097. Medline
Hafting T, Fyhn M, Molden S, Moser MB, Moser EI (2005) Microstructure of a spatial map in the entorhinal cortex. Nature 436:801-806. CrossRef Medline

Hafting T, Fyhn M, Bonnevie T, Moser MB, Moser EI (2008) Hippocampus-independent phase precession in entorhinal grid cells. Nature 453:1248-1252. CrossRef Medline

Hangya B, Borhegyi Z, Szilágyi N, Freund TF, Varga V (2009) GABAergic neurons of the medial septum lead the hippocampal network during theta activity. J Neurosci 29:8094-8102. CrossRef Medline

Hangya B, Li Y, Muller RU, Czurkó A (2010) Complementary spatial firing in place cell-interneuron pairs. J Physiol 588:4165-4175. CrossRef Medline

Hassani OK, Lee MG, Henny P, Jones BE (2009) Discharge profiles of identified GABAergic in comparison to cholinergic and putative glutamatergic basal forebrain neurons across the sleep-wake cycle. J Neurosci 29: 11828-11840. CrossRef Medline

Henny P, Jones BE (2008) Projections from basal forebrain to prefrontal cortex comprise cholinergic, GABAergic and glutamatergic inputs to pyramidal cells or interneurons. Eur J Neurosci 27:654-670. CrossRef Medline

Jeffery KJ, Donnett JG, O'Keefe J (1995) Medial septal control of thetacorrelated unit firing in the entorhinal cortex of awake rats. Neuroreport 6:2166-2170. CrossRef Medline

Jones MW, Wilson MA (2005) Theta rhythms coordinate hippocampalprefrontal interactions in a spatial memory task. PLoS Biol 3:e402. Medline

Katona L, Lapray D, Viney TJ, Oulhaj A, Borhegyi Z, Micklem BR, Klausberger T, Somogyi P (2014) Sleep and movement differentiates actions of two types of somatostatin-expressing GABAergic interneuron in rat hippocampus. Neuron 82:872-886. CrossRef Medline

Kim T, Thankachan S, McKenna JT, McNally JM, Yang C, Choi JH, Chen L, Kocsis B, Deisseroth K, Strecker RE, Basheer R, Brown RE, McCarley RW (2015) Cortically projecting basal forebrain parvalbumin neurons regulate cortical gamma band oscillations. Proc Natl Acad Sci U S A 112: 3535-3540. CrossRef Medline

King C, Recce M, O'Keefe J (1998) The rhythmicity of cells of the medial septum/diagonal band of Broca in the awake freely moving rat: relationships with behaviour and hippocampal theta. Eur J Neurosci 10:464-477. CrossRef Medline

Kiss J, Maglóczky Z, Somogyi J, Freund TF (1997) Distribution of calretinin-containing neurons relative to other neurochemically identified cell types in the medial septum of the rat. Neuroscience 78:399-410. CrossRef Medline

Kitamura T, Pignatelli M, Suh J, Kohara K, Yoshiki A, Abe K, Tonegawa S (2014) Island cells control temporal association memory. Science 343: 896-901. CrossRef Medline

Klink R, Alonso A (1997) Muscarinic modulation of the oscillatory and repetitive firing properties of entorhinal cortex layer II neurons. J Neurophysiol 77:1813-1828. Medline

Knierim JJ (2015) From the GPS to HM: place cells, grid cells, and memory. Hippocampus 25:719-725. CrossRef Medline

Koenig J, Linder AN, Leutgeb JK, Leutgeb S (2011) The spatial periodicity of grid cells is not sustained during reduced theta oscillations. Science 332: 592-595. CrossRef Medline

Köhler C, Chan-Palay V, Wu JY (1984) Septal neurons containing glutamic acid decarboxylase immunoreactivity project to the hippocampal region in the rat brain. Anat Embryol 169:41-44. CrossRef Medline

Lapray D, Lasztoczi B, Lagler M, Viney TJ, Katona L, Valenti O, Hartwich K, Borhegyi Z, Somogyi P, Klausberger T (2012) Behavior-dependent specialization of identified hippocampal interneurons. Nat Neurosci 15: 1265-1271. CrossRef Medline

Leão RN, Targino ZH, Colom LV, Fisahn A (2015) Interconnection and synchronization of neuronal populations in the mouse medial septum/ diagonal band of Broca. J Neurophysiol 113:971-980. CrossRef Medline

Leranth C, Carpi D, Buzsaki G, Kiss J (1999) The entorhino-septosupramammillary nucleus connection in the rat: Morphological basis of a feedback mechanism regulating hippocampal theta rhythm. Neuroscience 88:701-718. CrossRef Medline

Lewis PR, Shute CC (1967) The cholinergic limbic system: projections to hippocampal formation, medial cortex, nuclei of the ascending cholinergic reticular system, and the subfornical organ and supra-optic crest. Brain 90:521-540. CrossRef Medline 
Lingenhöhl K, Finch DM (1991) Morphological characterization of rat entorhinal neurons in vivo: soma-dendritic structure and axonal domains. Exp Brain Res 84:57-74. Medline

Linkenkaer-Hansen K, Monto S, Rytsälä H, Suominen K, Isometsä E, Kähkönen S (2005) Breakdown of long-range temporal correlations in theta oscillations in patients with major depressive disorder. J Neurosci 25: 10131-10137. CrossRef Medline

Markram H, Toledo-Rodriguez M, Wang Y, Gupta A, Silberberg G, Wu C (2004) Interneurons of the neocortical inhibitory system. Nat Rev Neurosci 5:793-807. CrossRef Medline

Maurer AP, Cowen SL, Burke SN, Barnes CA, McNaughton BL (2006) Phase precession in hippocampal interneurons showing strong functional coupling to individual pyramidal cells. J Neurosci 26:13485-13492. CrossRef Medline

McDonald AJ, Muller JF, Mascagni F (2011) Postsynaptic targets of GABAergic basal forebrain projections to the basolateral amygdala. Neuroscience 183:144-159. CrossRef Medline

McNaughton N, Ruan M, Woodnorth MA (2006) Restoring theta-like rhythmicity in rats restores initial learning in the Morris water maze. Hippocampus 16:1102-1110. CrossRef Medline

Megías M, Emri Z, Freund TF, Gulyás AI (2001) Total number and distribution of inhibitory and excitatory synapses on hippocampal CA1 pyramidal cells. Neuroscience 102:527-540. CrossRef Medline

Mizumori SJ, Perez GM, Alvarado MC, Barnes CA, McNaughton BL (1990) Reversible inactivation of the medial septum differentially affects two forms of learning in rats. Brain Res 528:12-20. CrossRef Medline

Mizuseki K, Sirota A, Pastalkova E, Buzsáki G (2009) Theta oscillations provide temporal windows for local circuit computation in the entorhinalhippocampal loop. Neuron 64:267-280. CrossRef Medline

Morris NP, Harris SJ, Henderson Z (1999) Parvalbumin-immunoreactive, fastspiking neurons in the medial septum/diagonal band complex of the rat: intracellular recordings in vitro. Neuroscience 92:589-600. CrossRef Medline

Morris NP, Fyffe RE, Robertson B (2004) Characterisation of hyperpolarization-activated currents $(\mathrm{I}(\mathrm{h}))$ in the medial septum/diagonal band complex in the mouse. Brain Res 1006:74-86. CrossRef Medline

Nyakas C, Luiten PG, Spencer DG, Traber J (1987) Detailed projection patterns of septal and diagonal band efferents to the hippocampus in the rat with emphasis on innervation of CA1 and dentate gyrus. Brain Res Bull 18:533-545. CrossRef Medline

Pang KC, Jiao X, Sinha S, Beck KD, Servatius RJ (2011) Damage of GABA ergic neurons in the medial septum impairs spatial working memory and extinction of active avoidance: effects on proactive interference. Hippocampus 21:835-846. Medline

Pastoll H, Solanka L, van Rossum MC, Nolan MF (2013) Feedback inhibition enables theta-nested gamma oscillations and grid firing fields. Neuron 77:141-154. CrossRef Medline

Paxinos G, Franklin KBJ (2003) Mouse brain in stereotaxic coordinates, 2nd edition. San Diego: Academic.

Petsche H, Stumpf C, Gogolak G (1962) The significance of the rabbit's septum as a relay station between the midbrain and the hippocampus. I. The control of hippocampus arousal activity by the septum cells. Electroencephalogr Clin Neurophysiol 14:202-211. CrossRef Medline

Rawlins JN, Feldon J, Gray JA (1979) Septo-hippocampal connections and the hippocampal theta rhythm. Exp Brain Res 37:49-63. CrossRef Medline

Simon AP, Poindessous-Jazat F, Dutar P, Epelbaum J, Bassant MH (2006) Firing properties of anatomically identified neurons in the medial septum of anesthetized and unanesthetized restrained rats. J Neurosci 26: 9038-9046. CrossRef Medline

Smith ML, Hale BD, Booze RM (1994) Calbindin-D28k immunoreactivity within the cholinergic and GABAergic projection neurons of the basal forebrain. Exp Neurol 130:230-236. CrossRef Medline

Somogyi P (2010) Hippocampus-intrinsic organisation. In: Handbook of brain microcircuits (Shepherd GM, Grillner S, eds), pp 148-164. Oxford: Oxford UP.

Somogyi P, Katona L, Klausberger T, Lasztóczi B, Viney TJ (2014) Temporal redistribution of inhibition over neuronal subcellular domains underlies state-dependent rhythmic change of excitability in the hippocampus. Philos Trans R Soc Lond B Biol Sci 369:20120518. CrossRef Medline

Sotty F, Danik M, Manseau F, Laplante F, Quirion R, Williams S (2003) Distinct electrophysiological properties of glutamatergic, cholinergic and GABAergic rat septohippocampal neurons: novel implications for hippocampal rhythmicity. J Physiol 551:927-943. CrossRef Medline

Stenvers KL, Zimmermann EM, Gallagher M, Lund PK (1994) Expression of insulin-like growth factor binding protein- 4 and -5 mRNAs in adult rat forebrain. J Comp Neurol 339:91-105. CrossRef Medline

Sun Y, Nguyen AQ, Nguyen JP, Le L, Saur D, Choi J, Callaway EM, Xu X (2014) Cell-type-specific circuit connectivity of hippocampal CA1 revealed through Cre-dependent rabies tracing. Cell Rep 7:269-280. CrossRef Medline

Takács VT, Klausberger T, Somogyi P, Freund TF, Gulyás AI (2012) Extrinsic and local glutamatergic inputs of the rat hippocampal CA1 area differentially innervate pyramidal cells and interneurons. Hippocampus 22 : 1379-1391. CrossRef Medline

Takeda K, Inoue H, Tanizawa Y, Matsuzaki Y, Oba J, Watanabe Y, Shinoda K, Oka Y (2001) WFS1 (Wolfram syndrome 1) gene product: predominant subcellular localization to endoplasmic reticulum in cultured cells and neuronal expression in rat brain. Hum Mol Genet 10:477-484. CrossRef Medline

Tang Q, Burgalossi A, Ebbesen CL, Ray S, Naumann R, Schmidt H, Spicher D, Brecht M (2014) Pyramidal and stellate cell specificity of grid and border representations in layer 2 of medial entorhinal cortex. Neuron 84: 1191-1197. CrossRef Medline

Tóth K, Freund TF, Miles R (1997) Disinhibition of rat hippocampal pyramidal cells by GABAergic afferents from the septum. J Physiol 500: 463-474. CrossRef Medline

Varga C, Lee SY, Soltesz I (2010) Target-selective GABAergic control of entorhinal cortex output. Nat Neurosci 13:822-824. CrossRef Medline

Varga C, Golshani P, Soltesz I (2012) Frequency-invariant temporal ordering of interneuronal discharges during hippocampal oscillations in awake mice. Proc Natl Acad Sci U S A 109:E2726-E2734. CrossRef Medline

Varga V, Hangya B, Kránitz K, Ludányi A, Zemankovics R, Katona I, Shigemoto R, Freund TF, Borhegyi Z (2008) The presence of pacemaker HCN channels identifies theta rhythmic GABAergic neurons in the medial septum. J Physiol 586:3893-3915. CrossRef Medline

Vertes RP, Kocsis B (1997) Brainstem-diencephalo-septohippocamapal systems controlling the theta rhythm of the hippocampus. Neuroscience 81:893-926. CrossRef Medline

Viney TJ, Lasztoczi B, Katona L, Crump MG, Tukker JJ, Klausberger T, Somogyi P (2013) Network state-dependent inhibition of identified hippocampal CA3 axo-axonic cells in vivo. Nat Neurosci 16:1802-1811. CrossRef Medline

Vinogradova OS (1995) Expression, control, and probable functional significance of the neuronal theta-rhythm. Prog Neurobiol 45:523-583. CrossRef Medline

Wang Y, Romani S, Lustig B, Leonardo A, Pastalkova E (2015) Theta sequences are essential for internally generated hippocampal firing fields. Nat Neurosci 18:282-288. CrossRef Medline

Watakabe A, Ohtsuka M, Kinoshita M, Takaji M, Isa K, Mizukami H, Ozawa $\mathrm{K}$, Isa T, Yamamori T (2015) Comparative analyses of adeno-associated viral vector serotypes $1,2,5,8$ and 9 in marmoset, mouse and macaque cerebral cortex. Neurosci Res 93:144-157. CrossRef Medline

Wei B, Huang Z, He S, Sun C, You Y, Liu F, Yang Z (2012) The onion skin-like organization of the septum arises from multiple embryonic origins to form multiple adult neuronal fates. Neuoscience 222:110-123. CrossRef Medline

Winson J (1978) Loss of hippocampal theta rhythm results in spatial memory deficit in the rat. Science 201:160-163. CrossRef Medline

Xue M, Atallah BV, Scanziani M (2014) Equalizing excitation-inhibition ratios across visual cortical neurons. Nature 511:596-600. CrossRef Medline

Zaborszky L, Pang K, Somogyi J, Nadasdy Z, Kallo I (1999) The basal forebrain corticopetal system revisited. Ann NY Acad Sci 877:339-367. CrossRef Medline 